\title{
Emerging Electrochemical Sensors for Real-Time Detection of Tetracyclines in Milk
}

\author{
Magdalena R. Raykova ${ }^{1}\left(\mathbb{D}\right.$, Damion K. Corrigan ${ }^{2}{ }^{(}$, Morag Holdsworth ${ }^{3}$, Fiona L. Henriquez ${ }^{4}$ \\ and Andrew C. Ward 1,* \\ 1 Civil and Environmental Engineering, University of Strathclyde, Glasgow G1 1XJ, UK; \\ magdalena.raykova@strath.ac.uk \\ 2 Biomedical Engineering, University of Strathclyde, Glasgow G1 1QE, UK; damion.corrigan@strath.ac.uk \\ 3 Graham's Dairy Family, Bridge of Allan, Stirling, Glasgow FK9 4RW, UK; \\ morag.holdsworth@grahamsfamilydairy.com \\ 4 School of Health and Life Sciences, University of the West of Scotland, Paisley PA1 2BE, UK; \\ fiona.henriquez@uws.ac.uk \\ * Correspondence: andrew.c.ward@strath.ac.uk
}

\section{check for}

updates

Citation: Raykova, M.R.; Corrigan, D.K.; Holdsworth, M.; Henriquez,

F.L.; Ward, A.C. Emerging

Electrochemical Sensors for

Real-Time Detection of Tetracyclines in Milk. Biosensors 2021, 11, 232.

https://doi.org/10.3390/bios11070232

Received: 27 May 2021

Accepted: 7 July 2021

Published: 9 July 2021

Publisher's Note: MDPI stays neutral with regard to jurisdictional claims in published maps and institutional affiliations.

Copyright: (c) 2021 by the authors. Licensee MDPI, Basel, Switzerland. This article is an open access article distributed under the terms and conditions of the Creative Commons Attribution (CC BY) license (https:// creativecommons.org/licenses/by/ $4.0 /$ )

\begin{abstract}
Antimicrobial drug residues in food are strictly controlled and monitored by national laws in most territories. Tetracyclines are a major broad-spectrum antibiotic class, active against a wide range of Gram-positive and Gram-negative bacteria, and they are the leading choice for the treatment of many conditions in veterinary medicine in recent years. In dairy farms, milk from cows being treated with antibiotic drugs, such as tetracyclines, is considered unfit for human consumption. Contamination of the farm bulk tank with milk containing these residues presents a threat to confidence of supply and results in financial losses to farmers and dairy. Real-time monitoring of milk production for antimicrobial residues could reduce this risk and help to minimise the release of residues into the environment where they can cause reservoirs of antimicrobial resistance. In this article, we review the existing literature for the detection of tetracyclines in cow's milk. Firstly, the complex nature of the milk matrix is described, and the test strategies in commercial use are outlined. Following this, emerging biosensors in the low-cost biosensors field are contrasted against each other, focusing upon electrochemical biosensors. Existing commercial tests that identify antimicrobial residues within milk are largely limited to beta-lactam detection, or non-specific detection of microbial inhibition, with tests specific to tetracycline residues less prevalent. Herein, we review a number of emerging electrochemical biosensor detection strategies for tetracyclines, which have the potential to close this gap and address the industry challenges associated with existing tests.
\end{abstract}

Keywords: antimicrobial resistance; tetracyclines; dairy; milk; electrochemical biosensors; antimicrobial residues

\section{Introduction}

Since their discovery and exploitation over 100 years ago, antimicrobial drugs have become an essential part of human and veterinary medicine [1]. Hundreds of individual drugs have been identified from natural sources or synthesised. Some examples of antibiotic classes include $\beta$-lactams (e.g., benzylpenicillin), tetracyclines, macrolides and aminoglycosides. Excessive use and exposure of antibiotics produce a global issue with a negative impact on their effectiveness, termed antimicrobial resistance (AMR) [2]. The emergence of AMR is caused by the use of antimicrobial drugs in veterinary practice as well as human medicine. In particular, in farming, apart from treating bacterial infections in food-producing animals, such as cattle, antimicrobials have been used for prophylactics and growth promotion [3]. This excessive use has been recognised as an unnecessary overuse in the European Union (EU), and although antibiotics for growth promotion have been banned, their prophylactic use is still legal [4]. 
The dairy industry represents a significant proportion of agricultural productivity in many countries globally. For example, within the UK, in 2018, dairy represented $16.9 \%$ of the agricultural output and had a market value of $£ 4.5$ billion [5]. Milk is used to produce a wide range of foods, such as yoghurt, cheese, butter and cream. If antimicrobial residues are present within milk, there is a negative effect on the processes that rely on microorganisms for production, such as yoghurt and cheese [6,7].

In addition, the presence of antimicrobial residues can have deleterious health impacts, such as the evolution of AMR within the gut microbiome and allergic reactions in sensitive individual consumers [8-10]. Therefore, to prevent this, authorities place legal limits on the concentrations of drug residues permitted. In the EU, Maximum Residue Limits (MRLs) are specified for all antimicrobial drugs indicated for veterinary use $[3,11]$. Within the EU, for example, these are defined in $\mu \mathrm{g}$ antibiotic per $\mathrm{kg}$ food product [12].

In the context of dairy farming, a cow eliminates antibiotics through the liver, kidneys and udder and many are excreted in an unchanged and active form via all three excretion routes [3]. Depending on drug solubility, antimicrobials are excreted by mammary gland in the range of $0.002-6.0 \%$ as the percentage recovery of administrated dose $[13,14]$. Given that antimicrobial residues can be present in milk from cows treated with antimicrobial drugs, it must be excluded from the milk supply chain to comply with regulations, protect human health and prevent downstream production processes. To support this, minimum withdrawal periods have been defined for each drug between the last administration and reintroduction of milk to the supply chain [15]. Despite this, traces of antibiotics are sometimes present in milk even after the withdrawal period [3]. Moreover, some antibiotic classes are found to be stable in a wide range of temperatures and are stable in milk even after a pasteurisation process reaching temperatures up to $100{ }^{\circ} \mathrm{C}$ [10].

Tetracyclines were discovered more than half a century ago [16], and the sale of tetracyclines has increased to the extent of becoming the leading choice of antibiotics used on farm animals and cows, in particular, within European countries. The general sale of antibiotics for use on food-producing animal species in the UK has been reported steady over the period between 2014 and 2019. In 2019 alone, 232.2 tonnes of active ingredients were sold in the category of farm animals with 12 tonnes for use on cattle only [17]. Tetracyclines are reported to be the most sold antibiotic class, with $32 \%$ of the total sale in 2019. Figure 1 is a comparison of the sale between tetracyclines and the second most sold antibiotic class-beta-lactams-between 2015 and 2019.

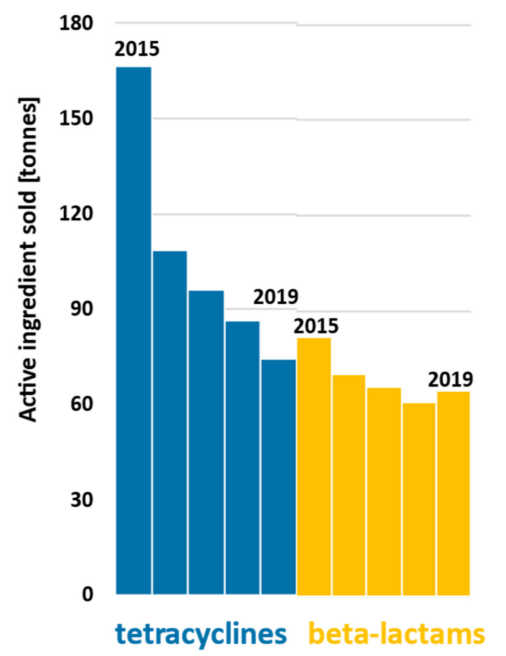

Figure 1. Sales of tetracyclines and beta-lactams between 2015 and 2019. (Data taken from UK-VARSS Report, 2019, Table 1.3) [17]. 
In addition to the legal implications of antimicrobial residues in milk, safe and effective disposal of the milk is also problematic. Two disposal routes have been set by the Food Standards Agency to dispose of contaminated milk. These are: discarding it in a slurry tank or spraying it over the land on the farm [18]. Both routes are a direct exposure of antimicrobials to the environment. Active and unchanged antibiotic molecules or their metabolites can then persist in the environment for long periods of time, driving antimicrobial resistance that can be passed onto farm animals and humans $[8,19]$. This makes the future treatment of bacterial infections more complicated to almost impossible in some cases [20]. Moreover, antimicrobial resistance is declared one of the top ten global public health threats facing humanity by the World Health Organisation (WHO) [21,22]. The ability to rapidly identify contaminated milk at the source provides more opportunities to dispose of milk economically. Furthermore, developing a greater understanding of the extent and persistence of antimicrobials from farming within the environment is essential to the development of focused mitigation strategies.

Biosensors are devices that have the capability to measure biological or chemical reactions in proportion to the concentration of a target analyte [23]. This technology has been widely employed in healthcare for monitoring health conditions, such as glucose levels in the blood (diabetes) or the presence of human chorionic gonadotropin (HCG) hormone in urine for pregnancy testing [24]. Biosensors can be developed to be rapid, low cost, easy to use and with little to no requirement for laboratory infrastructure. These properties make them attractive for use for farm monitoring and detection of antimicrobial residues in milk.

Real-time sensors for the detection of antimicrobial residues would be of great value at a number of different points in the milk supply chain. Several recent reviews focus upon the development of beta-lactam biosensors [25-28]. However, to the best of our knowledge, no up-to-date review exists on biosensors for the detection of tetracycline residues in milk. We address this gap here by providing a review of the latest literature on electrochemical sensors for real-time, low-cost detection of tetracycline residues in milk. We describe the important properties of the milk matrix and tetracycline drug class that are important from the perspective of biosensor development before going on to explaining the current techniques that are used to detect residues. This sets the context for the final part of our review, where we focus upon the latest research into electrochemical biosensors to detect tetracycline drugs. Non-electrochemical sensor approaches, such as optical and piezoelectric detection methods, are outside the scope of this review. For a comprehensive review on optical detection, see Chen and Wang, 2020 [29].

\section{Cow's Milk Properties and Antibiotic Behaviour}

Cow's milk is complex fluid composed of lipids, proteins, carbohydrates and minerals in aqueous phase [30]. It typically requires sample preparation and extraction prior to analysis to avoid possible interference between fractions.

\subsection{Raw Milk Composition}

As shown in Table 1, water content is very high in milk. Lactose is the main carbohydrate contained in milk and plays a significant role in fermentation. It also regulates the water content of milk; thus, its content is not a variable but mostly constant in milk. Other carbohydrates present in raw milk are monosaccharides (such as glucose), sugar phosphates and oligosaccharides [31]. 
Table 1. Cow's raw milk composition (g/100 g milk) and the main constituents of each fraction; depending on their solubility properties, different antibiotics bind to certain fractions of milk, examples listed.

\begin{tabular}{|c|c|c|c|c|}
\hline $\begin{array}{c}\text { Fraction of } \\
\text { Milk }\end{array}$ & $\begin{array}{c}\text { Content } \\
\text { (g/100 g Milk) }\end{array}$ & Main Constituents & $\begin{array}{l}\text { Antibiotics Likely to } \\
\text { Concentrate }\end{array}$ & Reference \\
\hline Water & 87.2 & - & $\begin{array}{l}\text { oxytetracycline } \\
\text { chlortetracycline } \\
\text { benzylpenicillin }{ }^{1} \\
\text { amoxicillin }^{2} \\
\text { sulfadimethoxine }^{3} \\
\text { ciprofloxacin }^{4}\end{array}$ & {$[30,32,33]$} \\
\hline Carbohydrates & 4.9 & $\begin{array}{c}\text { Lactose } \\
\text { Monosaccharide } \\
\text { Sugar phosphates } \\
\text { Oligosaccharides }\end{array}$ & - & {$[30]$} \\
\hline Fats & 3.7 & $\begin{array}{c}\text { Triglycerides } \\
\text { Phospholipids }\end{array}$ & $\begin{array}{l}\text { tetracycline } \\
\text { doxycycline } \\
\text { tylosin }{ }^{5} \\
\text { aminoglycosides } \\
\text { thiamphenicol }\end{array}$ & {$[30,32,34-36]$} \\
\hline Proteins & 3.5 & $\begin{array}{c}\text { Casein } \\
\text { Whey } \\
\text { Fat globule membrane }\end{array}$ & $\begin{array}{l}\text { chlortetracycline } \\
\text { tetracycline } \\
\text { doxycycline } \\
\text { tylosin }^{5}\end{array}$ & {$[30,32,35,37]$} \\
\hline Minerals & 0.72 & $\mathrm{Ca}, \mathrm{Na}, \mathrm{Mg}, \mathrm{P}, \mathrm{Cl}, \mathrm{K}$ & - & [30] \\
\hline
\end{tabular}

The fat content in cow's milk can be divided into simple and complex lipids known as triglycerides and phospholipids, respectively [30]. The main simple lipid is triacylglycerol, and half of its content is synthesised by the mammary gland, and the other half is derived directly from the bloodstream [31]. Simple lipids comprise $~ 90 \%$ of the fat content in milk. On the other hand, phospholipids contain phosphorus and/or nitrogen and can form bridges between fatty and aqueous phases of milk due to their amphiphilic properties. Examples of milk-containing phospholipids are lecithin, phosphatidyl choline and phosphatidyl ethanolamine [38].

Dairy proteins consist of $3.5 \mathrm{~g} / 100 \mathrm{~g}$ milk and can be divided into three classes as casein, whey and fat globule membrane protein, and they all contain vital amino acids [30]. Casein proteins have low solubility at $\mathrm{pH} 4.6$, and the four major ones are known as $\alpha_{\mathrm{s} 1}$, $\alpha_{\mathrm{s} 2}, \beta$ and $k$ caseins. Whey proteins are soluble in a wide range of $\mathrm{pH}$ and are often referred to as serum proteins, with major ones being $\alpha$-lactoglobulin and $\beta$-lactalbulin [39]. Fat globule membrane proteins are composed of both lipids and proteins and originate from the mammary gland epithelia [40]. They comprise only $~ 1-2 \%$ of the protein content of milk. A study analysing raw bovine milk had determined 20 different proteins categorised as the above classes and casein, whey and fat globule membrane proteins comprising of $80.4,13.5$ and $1.7 \mathrm{~g} / 100 \mathrm{~g}$ protein, respectively [41].

\subsection{Binding Properties of Antibiotics}

Depending on their solubility properties, antibiotic molecules are not distributed evenly through the milk and essentially are binding to different fractions [32,35]. Hydrophilic antibiotics (such as some $\beta$-lactams, sulphonamides and fluoroquinolones) would concentrate in skim milk due to the absence of fat; hence, lipophilic drugs (such as some macrolides, e.g., tylosin) would tend to concentrate in, for instance, cream. In Table 1 some examples of antibiotic classes are linked to the respective fraction of milk they are likely to concentrate in, depending on their solubility properties. Generally, tetracyclines are lipophilic antibiotics, with the exception of oxytetracycline and chlortetracycline. A study proves that lipophilic tetracyclines tend to concentrate in the fatty fractions on milk rather than in aqueous such as skimmed milk [32]. Fat percentage in milk varies between 
cows on a farm. For example, cattle breed is one of the main factors for variation of fat content in cow's milk. In particular, Jersey breed cows produce milk that is rich in lipids [31], suggesting that lipophilic tetracyclines would concentrate in Jersey cow's milk after administration.

Even though fats and carbohydrates comprise larger portions of bovine milk's composition, proteins are much larger molecules that consist of hundreds of amino acid chains and fold into themselves. Table 2 below demonstrates the molecular weight's significance of the major constituents of each fraction. The larger the molecule is, the larger the surface of binding it provides.

Table 2. Molecular weights of major constituents composing raw cow's milk fractions; Milk fractions being carbohydrates (lactose, glucose), fats (triacylglycerol, lecithin) and proteins (k casein, $\alpha$-lactoglobulin).

\begin{tabular}{ccc}
\hline Constituent & $\begin{array}{c}\text { Molecular Weight } \\
\text { (g/mol) }\end{array}$ & Reference \\
\hline Lactose & 342.3 & {$[42]$} \\
Glucose & 180.2 & {$[43]$} \\
Triacylglycerol & 855.4 & {$[44]$} \\
Lecithin & 758.1 & {$[45]$} \\
$k$ casein & 18974 & {$[46]$} \\
$\alpha$-lactoglobulin & 14178 & {$[47]$} \\
\hline
\end{tabular}

In fact, not only lipophilicity but also protein-binding properties play a significant role in antibiotic concentration distribution in milk. Some antimicrobial drugs (such as tylosin) tend to concentrate in casein protein fraction, for example [32]. In terms of tetracyclines, their protein-binding properties vary, with doxycycline having the highest range of $82-93 \%$. The hydrophilic oxytetracycline has the lowest range of $27-35 \%$; tetracycline and chlortetracycline's protein-binding properties range between $55-64 \%$ and $50-55 \%$, respectively [37]. Hence, lipophilicity has some impact on the protein-binding properties of antibiotics and must be carefully considered prior to any analysis.

\section{Chemical and Biological Properties of Tetracyclines}

Tetracyclines are broad-spectrum antibiotics that are active against a range of Grampositive and Gram-negative bacteria, as well as some intracellular bacteria, such as chlamydiae, mycoplasmas and rickettsiae, and protozoan parasites [48]. In particular, tetracyclines are used on cattle for the treatment of bovine respiratory diseases (BRD) and mastitis $[49,50]$. Tetracyclines can be sorted into three categories depending on the timeframe of their development. First-generation tetracyclines were discovered between 1948 and 1963, and second-generation tetracyclines in the period between 1965 and 1972 [16]. Thirdgeneration tetracyclines were discovered in 1993 and are called glycylcyclines. These have the advantage of being active against first- and second-generation tetracycline-resistant organisms [51].

The most widely used tetracyclines in veterinary medicine are chlortetracycline (CTC), oxytetracycline (OTC), tetracycline (TC) and doxycycline (DC). With respect to the above three categories, CTC, OTC and TC are first-generation tetracyclines, whereas DC is a second-generation tetracycline. Glycylcyclines are not authorised for use on animals due to the lack of a maximum residue limit set for them [52].

The chemical structure of all tetracyclines consists of a tetracene (or naphthacene) core (Figure 2) and similar functional groups [53]. The addition of molecules such as $(-\mathrm{Cl})$ or $(-\mathrm{OH})$ determines the derived names of CTC or OTC, for instance. However, all tetracyclines contain a phenol group that makes them electroactive substances [54]. 
<smiles>c1ccc2cc3cc4ccccc4cc3cc2c1</smiles>

Figure 2. The chemical structure of tetracene (or naphthacene)-the core of all tetracyclines.

The chemical properties of CTC, OTC, TC and DC are summarised in Table 3 below.

Table 3. The properties of commonly used tetracyclines in veterinary medicine (chemical data taken from PubChem).

\begin{tabular}{cccc}
\hline Active Ingredient & Molecular Formula & $\begin{array}{c}\text { Molecular Weight } \\
\text { (g/mol) }\end{array}$ & $\begin{array}{c}\text { Solubility } \\
\text { (mg/L) at 25 }{ }^{\circ} \mathbf{C}\end{array}$ \\
\hline Chlortetracycline & $\mathrm{C}_{22} \mathrm{H}_{23} \mathrm{ClN}_{2} \mathrm{O}_{8}$ & 478.9 & $\sim 500$ \\
Oxytetracycline & $\mathrm{C}_{22} \mathrm{H}_{24} \mathrm{~N}_{2} \mathrm{O}_{9}$ & 460.4 & 312 \\
Tetracycline & $\mathrm{C}_{22} \mathrm{H}_{24} \mathrm{~N}_{2} \mathrm{O}_{8}$ & 444.4 & 231 \\
Doxycycline & $\mathrm{C}_{22} \mathrm{H}_{24} \mathrm{~N}_{2} \mathrm{O}_{8}$ & 444.4 & 50000 \\
\hline
\end{tabular}

\subsection{Mode of Action}

In cattle, tetracyclines are used to treat infections mainly caused by Pasteurella multocida, Mannheimia haemolytica and Histophilus somni [49]. This antibiotic class demonstrates a bacteriostatic activity; therefore, these antimicrobials inhibit the growth of bacteria [55]. Tetracyclines tend to bind mainly to the $30 \mathrm{~S}$ ribosomal subunit with high affinity and prevent protein synthesis, as shown in Figure 3. However, this is reversible, and if the antibiotic is displaced, protein synthesis will continue within the bacterial cell $[16,48]$.

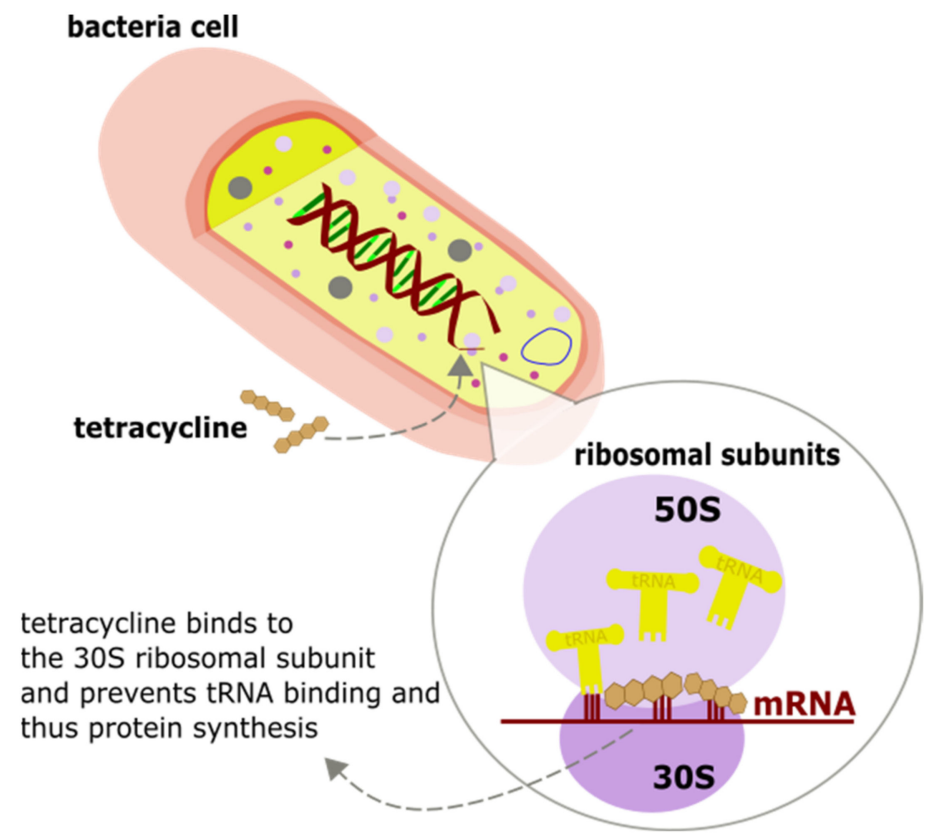

Figure 3. The mode of action of tetracyclines; bacterial cell inhibition by binding to the $30 \mathrm{~S}$ ribosomal subunit and protein synthesis prevention.

\subsection{Biotransformation, Excretion Routes and Withdrawal Time}

Tetracyclines are generally not metabolised and are excreted from the body unchanged, with the exception of TC, $5 \%$ of which is metabolised to a less active metabolite called 4 -epitetracycline $[37,56]$. All tetracyclines are excreted mainly via the liver $(>50 \%)$ and kidneys $(\leq 30 \%)$ or bind to tissues; however, $0.3 \%$ have been reported to be eliminated via the udder [14]. 
Withdrawal time can vary between antibiotic manufacturers, even with the same active ingredient ranging from 6 to 14 days. There are a couple of sprays used on cattle for dermatitis, for example, containing CTC or OTC that are reported to not have any effect on milk as per prescription. Their withdrawal time is said to be zero hours [57]. Terramycin is one of the most commonly used commercially available antibiotics containing the active ingredient of oxytetracycline. Its withdrawal period time for milk from cattle is listed to be 5 days [58].

\subsection{MRL and Evidence of Presence in Milk}

The maximum allowance for tetracyclines to be present solely or in a combination in milk is set at $100 \mu \mathrm{g} / \mathrm{L}$ in the EU and by the Food and Agricultural Organisation (FAO) and the WHO [11,12,59]. However, the US Food and Drug Administration (FDA) had set the limit of the sum of tetracyclines to be $300 \mu \mathrm{g} / \mathrm{kg}$ [60]. As mentioned earlier, some antibiotics are found to be stable in a wide range of temperatures, and tetracyclines are one of these antimicrobial agents [61]. A study examined tetracycline and oxytetracycline's stability under pasteurisation $\left(85^{\circ} \mathrm{C}\right)$ conditions, and both antibiotics were found to be relatively stable after processing with only $5.7 \%$ and $15.3 \%$ activity decrease, respectively [62]. The results of another study testing dairy products after pasteurisation and skimming process for traces of tetracyclines transferred from raw contaminated milk showed that the highest residues were found in curd, cheese and buttermilk with the highest residue values of $482 \mu \mathrm{g} / \mathrm{kg}, 561 \mu \mathrm{g} / \mathrm{kg}$ and $221 \mu \mathrm{g} / \mathrm{kg}$, respectively [63].

Numerous researchers had tested raw or processed cow's milk collected directly from farms or supermarkets and have detected tetracyclines above the allowed limit $[3,64-66]$. A couple of studies conducted in Iran, for example, had found tetracyclines in milk at a much higher concentration than $100 \mu \mathrm{g} / \mathrm{L}$ with a sample containing a concentration $2.5 \times$ higher than the allowed limit [64,67]. Another study completed in Turkey had analysed 100 raw milk samples for CTC, TC and OTC and found an average range of antimicrobials of 45.56-98.30 $\mu \mathrm{g} / \mathrm{L}$ and the highest value of $135.32 \mu \mathrm{g} / \mathrm{L}$ of TC [68].

\subsection{Persistence in the Environment}

As mentioned in the introduction, one way of disposal of contaminated milk is by discarding it in a slurry tank or spraying it over the land on the farm. Tetracycline has been reported not only to be eliminated from the body in an active and unchanged form but was also found to persist and accumulate in the soil over a few months [69].

Oxytetracycline was found to persist in soil but with low mobility and therefore does not move easily to aquatic environments nearby [70]. The persistence in the soil was also reported by analysing soil for the presence of chlortetracycline, which was believed to be the most common tetracycline antibiotic found in the environment [71]. It is worth reporting that tetracyclines tend to form complexes with metal cations, particularly with calcium, magnesium, copper and chromium [72].

As discussed earlier, antimicrobial resistance is a major crisis occurring in the environment and in the human body. The first tetracycline-resistant bacteria strain was found in 1953 in Shigella sp. bacteria [16]. Since then, tetracycline resistance has been increasing and occurring in both human and animal bodies and in the environment due to constant exposure [73-75].

\section{Existing Residue Test Methods}

Two principal test methods are in use to ensure the safety standards of food, such as milk and meat, are met in terms of drug residues [76,77]. Existing on-site tests for drug residues in milk rely on one of two approaches. The first involves inhibition of a microorganism in the presence of antimicrobial residues [78], and the second involves antibodies immobilised on a surface, specific for the given residue, which can then be transduced into a human-readable signal [79]. These tests are useful for screening bulk milk 
on the farm before it is transferred into the tanker for transportation. Both approaches have merits from the perspective of biosensors and therefore are discussed in more detail below.

In addition to these practical, in-field screening techniques, more robust and accurate confirmatory methods (e.g., HPLC) are typically used to verify the bulk milk prior to offloading from the tanker and processing. One of the key challenges in the identification of antimicrobial residues relates to the fact that the further through the production chain contaminated milk travels, the greater the economic and environmental consequences because a greater quantity of milk must be discarded (Figure 4).

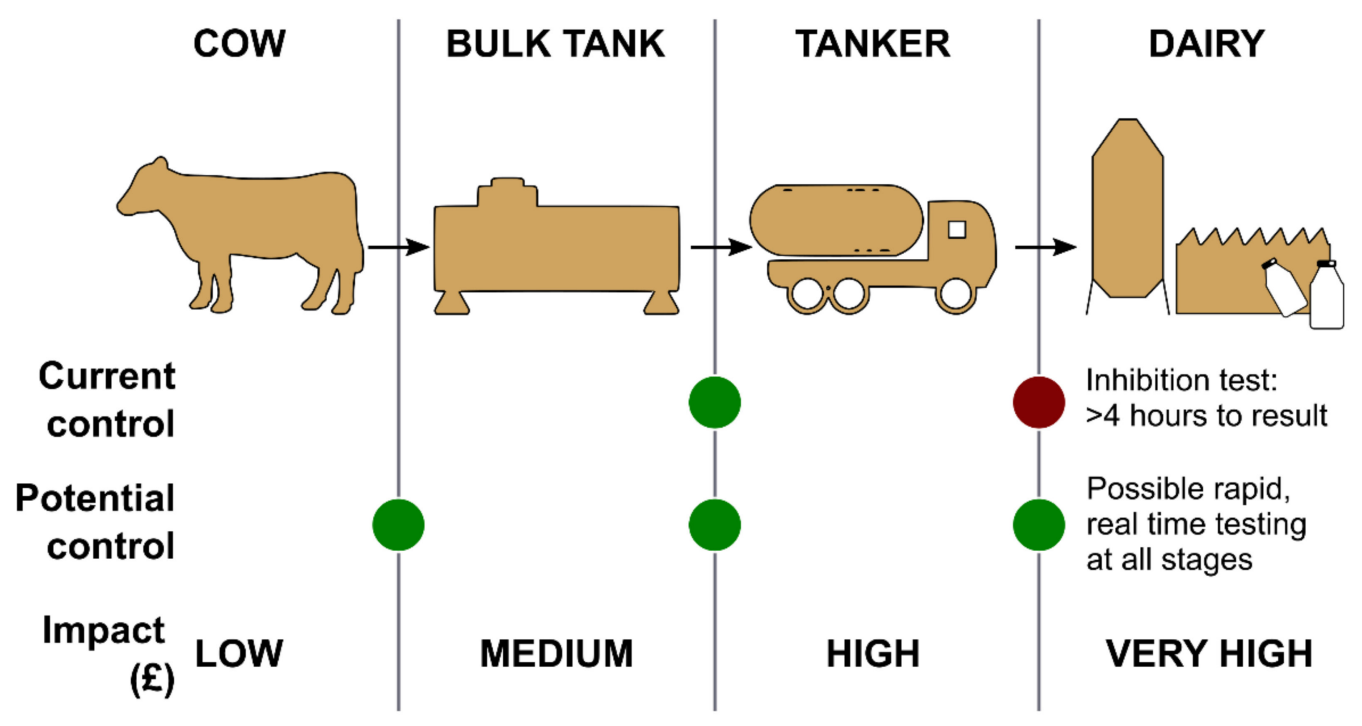

Figure 4. Current and potential testing checkpoints within the dairy supply chain, where financial impact increases with each step of testing towards the retailer.

Figure 4 also marks potential checkpoints within the dairy chain where essentially biosensors could be implemented. As shown, in the absence of proper measures, the financial impact increases at each checkpoint within the chain, reaching huge financial losses and even litigation if contaminated milk is sold to customers.

\subsection{Commercially Available Screening Tests}

Commercial microbial inhibition and antibody tests are widely used within the dairy industry for testing milk at the early stages of the supply chain. These tests are effective for on-site testing and cost-effective when used in bulk milk, although a key disadvantage of both of them is that they are qualitative and rely upon the user to interpret the test result; in borderline cases, this could lead to a false-negative result.

\subsubsection{Microbial Inhibition Test}

Microbial inhibition tests rely on the use of well-characterised indicator organisms with known sensitivities to antibiotic drugs. Geobacillus stearothermophilius, for example, is used in the ISO standard tube diffusion test (Figure 5) [78]. Delvotest ${ }^{\circledR}$ is the leading commercial microbial inhibition test with many variations. It has a relatively broad spectrum of antibiotic detection with a focus on $\beta$-lactams. Other antibiotic classes include macrolides, aminoglycosides, tetracyclines and sulfonamides. It is based on the growth of incubated bacteria within tubes or on a disk (in agar). As seen in Figure 5, when the sample is introduced in the tubes, if antibiotics are absent in the matrix, bacteria will grow, resulting in a drop in $\mathrm{pH}$. This change in $\mathrm{pH}$ is then measured using an indicator dye within the growth media. If antibiotics are present in the sample, the indicator organism will not grow, and there will be no colour change in the tube. 


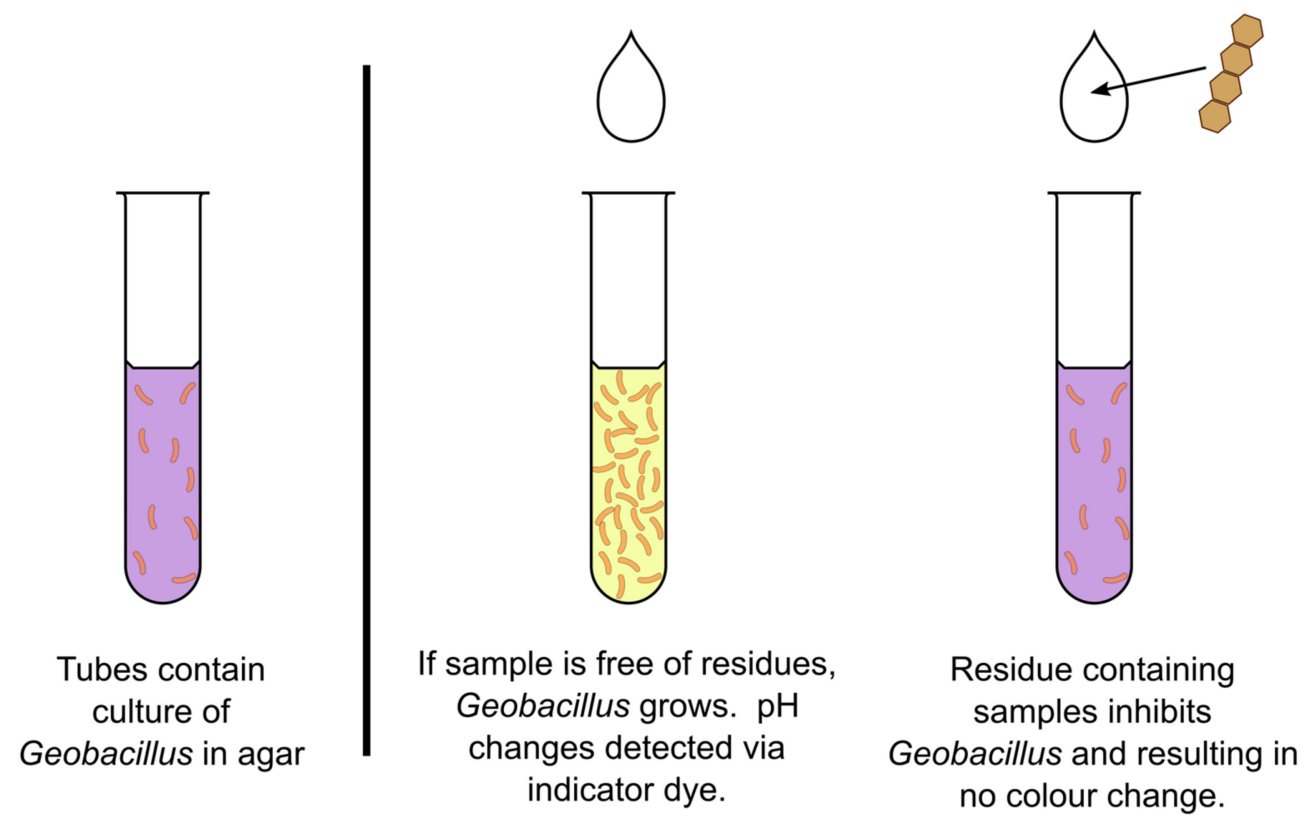

Figure 5. A schematic diagram of the microbial inhibition test for the detection of antimicrobial residues in milk.

The limit of detection for tetracyclines ranges from 100 to $>800 \mu \mathrm{g} / \mathrm{kg}$. The main drawback of this test is that it requires long incubation periods and, therefore, cannot be used in real-time [80].

\subsubsection{Immune Receptor Tests}

A commercial example of an immune receptor test is Charm ${ }^{\circledR}$. It involves the preparation of an antibody-antibiotic complex as a 'control' and a free antibody on the surface. When the sample is introduced, the target antibiotic molecule binds to the free antibody and forms a 'test' antibody-antibiotic complex. Both 'test' and 'control' complexes then compete for the immune receptor, enzyme, for example. The result is based on the intensity of the 'test' and 'control' reactions. It is essentially a positive or negative result [81]. These tests are more expensive than microbial inhibition tests and require lab equipment and conditions when preparing the antibodies. They also have a very limited range of analytes, usually targeting $\beta$-lactam antibiotics, and due to their working principle, they are, therefore, unsuitable for real-time analysis in the field.

\subsection{Laboratory-Based Analysis Techniques}

More sensitive and laboratory-based techniques such as chromatography are also used for milk analysis. These are sometimes conducted at the processing plant as a confirmation before processing raw milk (red control dot in Figure 4). The analysis is generally carried out with high-performance liquid chromatography (HPLC). Other methods include thinlayer chromatography (TLC) and gas chromatography (GC). Protein extraction and sample clean-up of milk are required before analysis. This can involve strong chemicals and solidphase extraction, which is expensive and time-consuming [61]. HPLC is also used for the determination of lactose content in dairy products after processing [82].

As mentioned, some antimicrobials have high protein-binding abilities; hence, the removal of proteins from the matrix can eliminate a portion of the antibiotics present in the sample.

\section{Emerging Electrochemical Biosensors for Tetracycline Residues}

Electrochemical biosensors are attractive and widely used because they offer advantages of low overall cost, quicker assay time and opportunities for miniaturization of the 
platform $[83,84]$. A number of different strategies can be employed to electrochemically transduce a biorecognition reaction with tetracycline residues, as shown in Figure 6. Electrochemical analytical techniques broadly fall into one of three groups: potentiometric, amperometric and impedimetric [85]. In a typical electrochemical cell, three electrodes are used, although in some cases, two-electrode or four-electrode systems can be employed. A three-electrode cell consists of a working electrode (WE), a reference electrode (RE) and a counter electrode (CE). The WE (often platinum, gold or carbon) is generally modified with biorecognition elements to achieve specific and sensitive transduction of the biomarker of interest with the electrode. The $\mathrm{CE}$ and $\mathrm{RE}$ are used to provide a return path for the current generated at the WE and to control the potential of the WE, respectively. Measurement is then performed with an instrument called a potentiostat, which is capable of sensing the electrochemical properties of the WE.

Detection Methods

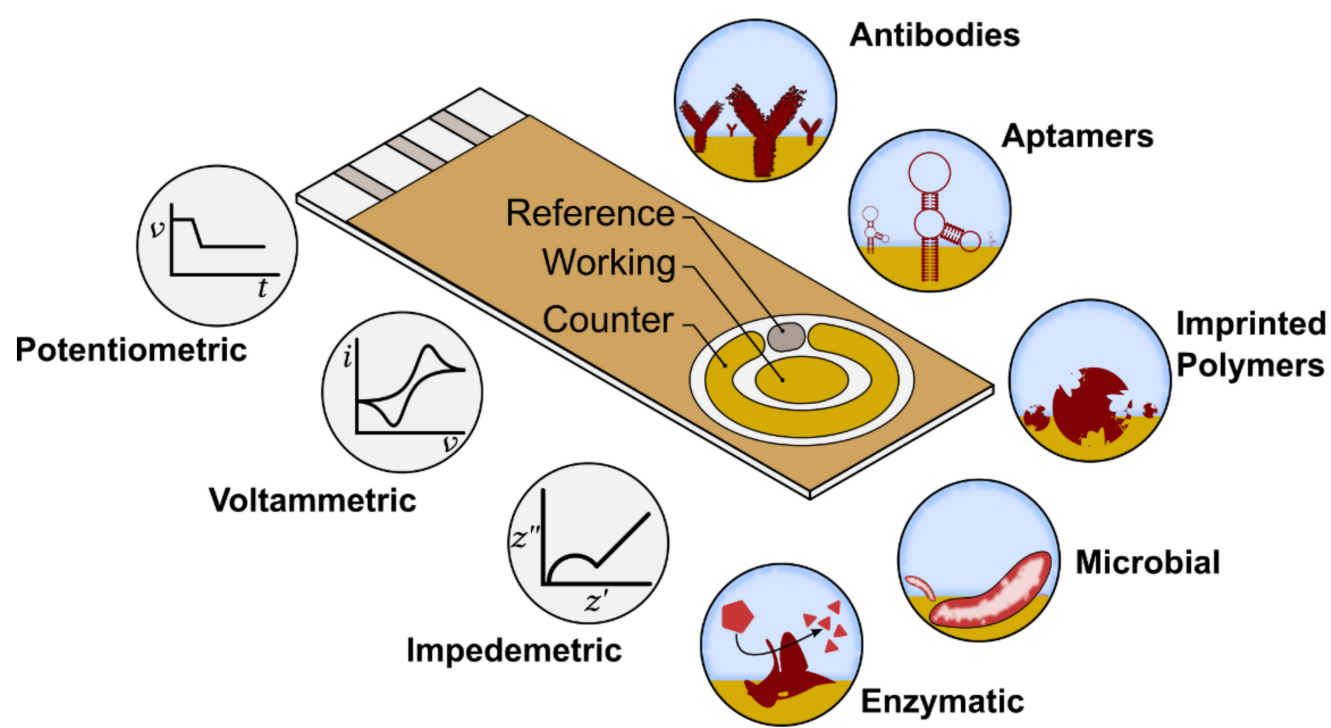

Figure 6. Electrochemical detection in a biosensor, where reference, working and counter respond to electrodes, which are arranged in a manner allowing the sample to be in contact with all three at the same time. The range of surface modifications is performed on the working electrode, which acts as the transducer in the biorecognition reaction.

Potentiometry is a well-known detection method based on the measurement of the potential at the surface of an electrode using a voltmeter [86,87]. In amperometric detection, a potential is applied to the $\mathrm{WE}$, and oxidation or reduction reactions produce a measurable current $[86,88]$. Impedance spectroscopy is based on the perturbation of the WE with sinusoidal potentials of differing frequencies, which allow the conductance and capacitance of the electrochemical cell to be determined [89]. All three detection methods are employed in biosensors for the detection of tetracyclines, as described below.

\subsection{Tetracycline Detection Strategies}

A number of detection strategies have been employed to electrochemically detect tetracycline residues. These can be broken down into six principal categories: enzyme-based, microbial inhibition, antibody-based, molecularly imprinted polymer-based, aptamerbased and direct detection. In this section, we explore each of these detection approaches in detail and give specific examples of developed biosensors in Table 4. 
Table 4. Examples of electrochemical biosensors for tetracycline residues detection defined by main parameters used for the description of any biosensor.

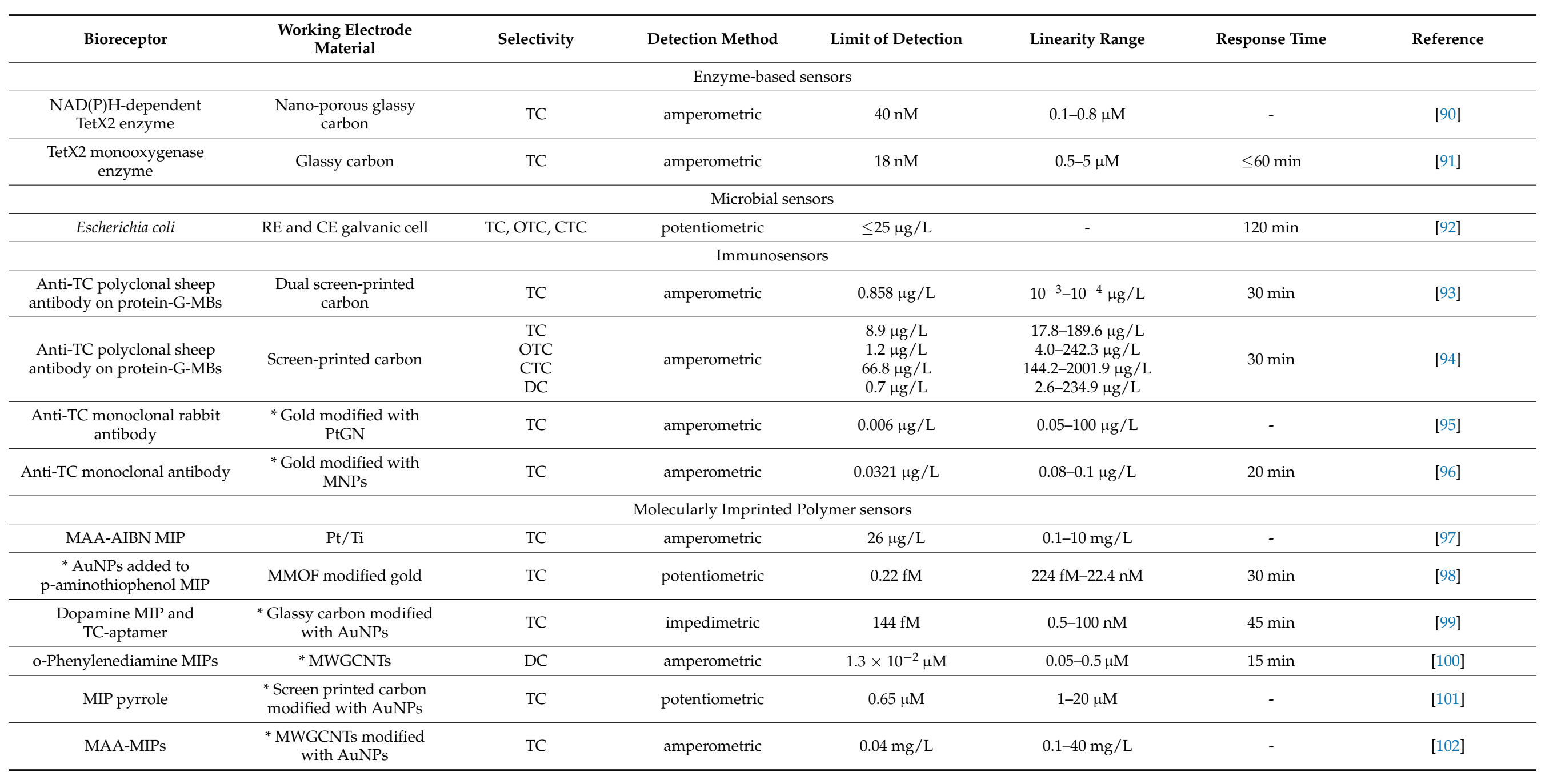


Table 4. Cont.

\begin{tabular}{|c|c|c|c|c|c|c|c|}
\hline Bioreceptor & $\begin{array}{l}\text { Working Electrode } \\
\text { Material }\end{array}$ & Selectivity & Detection Method & Limit of Detection & Linearity Range & Response Time & Reference \\
\hline \multicolumn{8}{|c|}{ Aptasensors } \\
\hline $\begin{array}{l}\text { 39-mer thiolated } \\
\text { TC-binding aptamer }\end{array}$ & $\begin{array}{l}\text { * Pencil graphite modified } \\
\text { with AuNPs/RGO }\end{array}$ & $\mathrm{TC}$ & impedimetric & $3 \times 10^{-17} \mathrm{M}$ & $10^{-16}-10^{-6} \mathrm{M}$ & $90 \mathrm{~min}$ & [103] \\
\hline $\begin{array}{l}\text { M-shaped aptamer } \\
\text { (Apt-CSs) with Exo I }\end{array}$ & Gold & $\mathrm{TC}$ & amperometric & $0.74 \mathrm{nM}$ & $1.5 \mathrm{nM}-3.5 \mu \mathrm{M}$ & - & [104] \\
\hline TC-aptamer & Glassy carbon & TC, OTC & amperometric & $1 \mu \mathrm{g} / \mathrm{L}$ & $0.1-100 \mu \mathrm{g} / \mathrm{L}$ & $5 \mathrm{~min}$ & [105] \\
\hline TC-aptamer & Gold & $\mathrm{TC}$ & impedimetric & $10 \mu \mathrm{g} / \mathrm{L}$ & $10-3000 \mu \mathrm{g} / \mathrm{L}$ & $15 \mathrm{~min}$ & [106] \\
\hline ssDNA aptamer & Screen-printed gold & $\mathrm{TC}$ & amperometric & $10 \mathrm{nM}$ & $10 \mathrm{nM}-10 \mu \mathrm{M}$ & - & [107] \\
\hline$\beta$-cyclodextrin-aptamer & Gold & $\mathrm{TC}$ & impedimetric & $0.008 \mathrm{nM}$ & $0.01-100 \mathrm{nM}$ & - & [108] \\
\hline $\begin{array}{l}\text { Amino modified } \\
\text { aptamer }\end{array}$ & Glassy carbon & OTC & impedimetric & $2.29 \times 10^{-10} \mathrm{~g} / \mathrm{mL}$ & $10^{-9}-10^{-4} \mathrm{~g} / \mathrm{mL}$ & $60 \mathrm{~min}$ & [109] \\
\hline ssDNA aptamer & $\begin{array}{l}\text { Single walled carbon } \\
\text { nanotube }\end{array}$ & OTC & amperometric & $1.125 \mu \mathrm{g} / \mathrm{L}$ & $10-75 \mu \mathrm{g} / \mathrm{L}$ & $10 \mathrm{~min}$ & [110] \\
\hline $\begin{array}{l}\text { TC-aptamer and multi-walled } \\
\text { carbon nanotubes }\end{array}$ & $\begin{array}{l}\text { * Glassy carbon modified } \\
\text { with MWCNTs }\end{array}$ & $\mathrm{TC}$ & amperometric & $5 \mathrm{nM}$ & $10^{-8}-10^{-5} \mathrm{M}$ & $30 \mathrm{~min}$ & [111] \\
\hline TC-aptamer & $\begin{array}{c}\text { * Glassy carbon modified } \\
\text { with graphene oxide } \\
\text { nanosheets }\end{array}$ & $\mathrm{TC}$ & impedimetric & $29 \mathrm{fM}$ & $0.1 \mathrm{pM}-10 \mu \mathrm{M}$ & $50 \mathrm{~min}$ & [113] \\
\hline TC-aptamer & $\begin{array}{l}{ }^{*} \mathrm{rGo}^{-} \mathrm{Fe}_{3} \mathrm{O}_{4} / \text { sodium } \\
\text { alginate modified } \\
\text { screen-printed carbon }\end{array}$ & $\mathrm{TC}$ & amperometric & $0.6 \mathrm{nM}$ & $1 \mathrm{nM}-5 \mu \mathrm{M}$ & - & [114] \\
\hline $\begin{array}{l}\text { TC-aptamer and bio-cDNA } \\
\text { aptamer }\end{array}$ & $\begin{array}{c}\text { * Glassy carbon modified } \\
\text { with } \mathrm{MoS}_{2}-\mathrm{TiO}_{2} @ \mathrm{Au} \\
\text { composite }\end{array}$ & $\mathrm{TC}$ & amperometric & $0.05 \mathrm{nM}$ & $0.15 \mathrm{nM}-6.0 \times 10^{-6} \mathrm{M}$ & $80 \mathrm{~min}$ & [115] \\
\hline
\end{tabular}

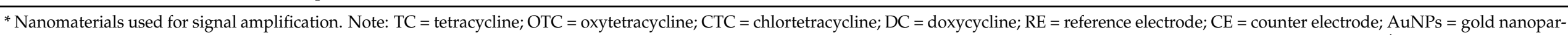

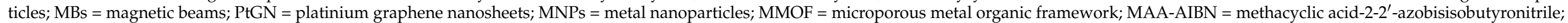

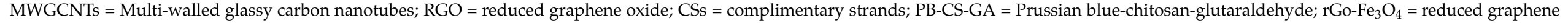
oxide-magnetite; bio-cDNA = biotin complementary DNA; $\mathrm{MWCNTs}=$ multi-walled carbon nanotubes 


\subsubsection{Immunosensors}

Immunosensors utilise the natural ability of antibodies to bind with high affinity to a target molecule or antigen (see Pollap et al. for a comprehensive review on the subject [116]). The binding affinity constant, expressed as $\mathrm{Kd}$, of an antibody is a useful parameter for its performance evaluation in a sensing platform [117]. The higher the Kd value, the smaller amount of target species would be detected.

A competitive assay was developed by Conzuelo et al. for tetracycline and sulphonamide detection [93]. In this approach, the investigators immobilised polyclonal sheep antibodies onto the surface of the electrode and with Horseradish peroxidase (HRP) tagged tetracycline. $\mathrm{HRP}$ used $\mathrm{H}_{2} \mathrm{O}_{2}$ as the enzyme substrate and hydroquinone as a redox mediator to generate a measurable current. When unlabelled tetracycline residues are present in the sample, the HRP-tagged tetracycline is displaced from the electrode's surface, and a measurable change in current is observed. Figure 7 is a representative diagram of this competitive electrochemical immunosensor and the chemistry on the surface of the electrode.

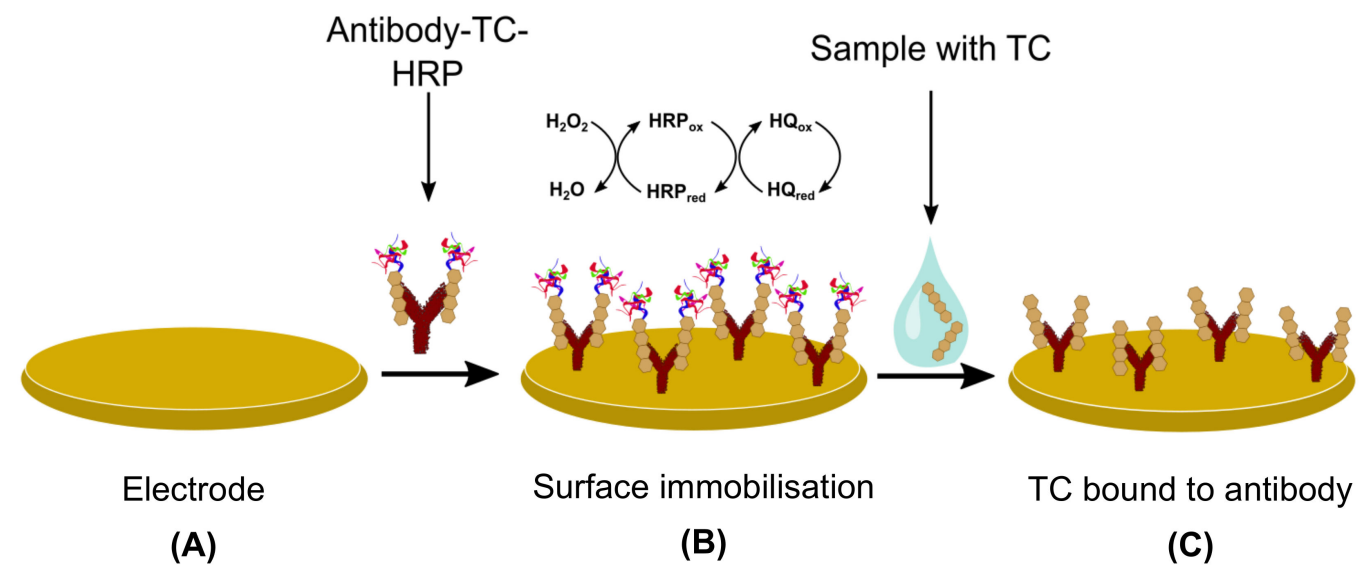

Figure 7. A schematic example of a competitive electrochemical immunosensor for the detection of tetracycline (TC). In this example, HRP is used to amplify the signal and identify the presence of TC. (A) The gold electrode surface is cleaned ready to receive a (B) TC antibody. After immobilisation on the surface, HRP tagged TC is added, which generates $\mathrm{H}_{2} \mathrm{O}_{2}$ in the presence of hydroquinone. Several strategies exist for the detection of $\mathrm{H}_{2} \mathrm{O}_{2}$ at an electrode surface. (C) When a sample is added containing TC, the HRP-TC complex is displaced from the antibody, and a drop in $\mathrm{H}_{2} \mathrm{O}_{2}$ production is electrochemically observed. Adapted from Conzuelo et al. [93].

A biosensor developed by Que et al. using monoclonal rabbit antibodies had achieved very low detection limits of $0.006 \mu \mathrm{g} / \mathrm{L}$ [95]. They added biolabelled graphene sheets to the sample with platinum nanoparticles that catalysed a hydrogen evolution reaction (HER) and enhanced the signal.

The use of nanoparticles has also been reported by Liu et al. [96]. Magnetic nanoparticles modified with chitosan have also been used for simple and low-cost immunosensors with anti-TC monoclonal antibodies. MNPs offer good biocompatibility, low toxicity and high electron transfer. Chitosan films were used for their advantageous properties, including membrane forming ability, high mechanical strength and easy chemical modification. Detection limits as low as $0.03 \mu \mathrm{g} / \mathrm{L}$ were attained.

\subsubsection{Enzyme-Based Sensors}

Enzyme-based sensors utilize specific enzymes in order to generate a bio-recognition reaction. The most well-known enzyme-based electrochemical biosensor is the blood glucose meter, which uses enzymes, such as glucose oxidase or glucose dehydrogenase, to measure glucose concentrations [118]. Besharati et al. used TetX2 monooxygenase for tetracycline detection achieving lower detection limits of $18 \mathrm{nM}$ [91]. TetX2 monooxygenase 
is an enzyme isolated transposon from CTnDOT in Bacteroides thetaoiotaomicron. It contains flavin and requires $\mathrm{NAD}(\mathrm{P}) \mathrm{H}$ to catalyse the biotransformation of tetracycline to 11-athetaoiothaomicron [119]. Hence, the addition of NAD $(\mathrm{P}) \mathrm{H}$ on the surface of the electrode resulted in its oxidation and improved response. However, the sensor is reported to require an hour from sample to result and wasn't tested on raw milk samples [91]. Using the same enzyme, this sensor has been further developed with low limits of TC detection, which were confirmed by HPLC [90].

One of the drawbacks of enzyme-based sensors is that they can have very low specificity, leading to a false-positive result, particularly if molecules with similar chemical structures are present in the sample [120]. This might explain why few enzyme-based biosensors for the detection of tetracyclines have been reported.

\subsubsection{Microbial Inhibition Sensors}

Microbial inhibition biosensors use the same principle as the tube diffusion test [78]; that is, the growth of sensitive microorganisms will be prevented or inhibited in the presence of the antimicrobial residue. The complex biochemistry of microorganisms means that a range of different parameters can be measured to determine inhibition, including $\mathrm{pH}$ and temperature changes [121]. Despite the opportunities, this provides for numerous electrochemical transduction strategies, few investigators have used this approach. Possible reasons for this are the long response times, the lack of quantitation of residue concentration and the non-specific nature of the approach for particular classes of residue. In one study, good sensitivity of tetracycline, oxytetracycline and chlortetracycline was found, but it took at least two hours for the sensor to detect the presence of residues [92].

\subsubsection{Direct Electrochemical Detection Techniques}

Electrochemical sensors can be also developed without the use of biological material; hence, a direct detection on the surface of the electrode is achieved [122]. This technique relies upon the electroactive properties of the targeted antibiotics. For instance, tetracyclines contain redox-active groups in their chemical structure, allowing a direct electron transfer and producing a detectable electrochemical flow on the electrode's surface [123]. Figure 8 is a generic schematic diagram of the direct detection of tetracycline on the surface of an electrode.

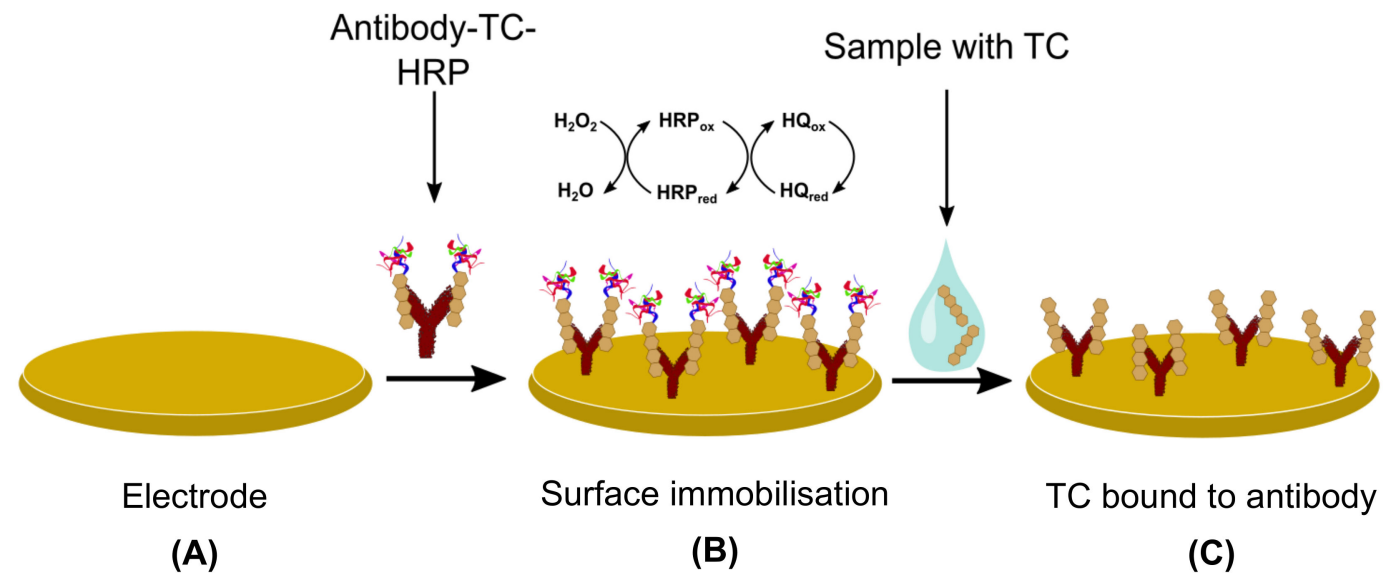

Figure 8. A schematic example of direct detection of tetracycline (TC). At high oxidation potentials, TC can be directly oxidized without dependence upon an affinity agent. After cleaning the electrode surface (A), an anti-fouling passivation layer is added to the electrode to create an alkanethiol layer (B). (C) at high oxidation potentials $(0.85 \mathrm{v} \mathrm{vs} \mathrm{Ag} / \mathrm{AgCl})$, TC is oxidised, resulting in a Faradaic charge transfer proportional to the concentration of TC present.

Screen-printed electrodes (SPEs) make attractive and affordable transducers for direct detection [124]. Modification of their surface, however, is typically required to enhance 
the electron transfer with the analyte. Often, such modification is achieved chemically using self-assembled monolayers (SAMs) that offer high molecular organisation and homogeneity [125]. Asadollahi-Baboli et al. report an example of modified SPE with SAM of cysteine on gold nanoparticles for simultaneous detection of tetracycline and cefixime (a cephalosporin) in milk [126]. Tetracycline was proved oxidizable; however, a tandem with chemometrics was required for optimal results. After careful consideration of the literature combined with previous work, the optimal $\mathrm{pH}$ of 2.9 was chosen for the buffer media. Empirically, it was discovered that the chosen $\mathrm{pH}$ provided the best results. The authors do not provide a further explanation for this. The redox properties of several organic molecules are known to change at different $\mathrm{pH}$ values, and presumably, a similar effect is at play with tetracycline at acidic $\mathrm{pH}$, leading to the authors' observations [127]. A prediction set, as well as a calibration set of solutions, were used to construct and evaluate the experimental design, which produced limits of detection of $0.52 \mu \mathrm{M}$ for tetracycline in milk. Even though this state-of-the-art sensor does not fall within the requirements of LOD values below the stated MRLs for tetracycline, it is a good description of a possible way of detection of the redox-active analyte. Tetracycline behaviour in alkaline and neutral $\mathrm{pH}$ discussed by Anderson et al. [127].

Graphene-modified screen-printed carbon electrode was used for direct detection of tetracycline in milk by Filik et al., achieving a limit of detection down to $80 \mathrm{mM}$ [128]. The milk samples, however, must be prepared and cleaned up by either solid-phase extraction or preliminary separation. Such sample preparation is not convenient practice in the field.

Direct electrochemical detection is generally not used for the analysis of complex matrices and milk as such. The lack of an immobilised bioreceptor reduces the specificity and the presence of other non-targeted, but redox-active compounds can only interfere with the signal and produce inaccurate results [122].

\subsubsection{Molecularly Imprinted Polymer (MIP) Sensors}

MIP biosensors are based on the creation of synthetic materials containing specific receptor sites having a high affinity toward the target molecule. These are cross-linked organic structures containing pre-designed molecular recognition sites complementary in shape, size and functional groups to the template molecule [129]. A more detailed and comprehensive review of MIP biosensors was reported by Gui et al. [130]. A number of different approaches can be used to create MIPs, including the production of MIP particles for later integration into end use applications, such as sensors [131] and direct electropolymerisation onto the surface of a substrate [132].

MIPs have been used for the impedimetric detection of doxycycline [100]. $O$-Phenylenediamine was electropolymerized on the surface of a multi-walled glassy carbon nanotubes electrode. The use of carbon nanotubes provided a larger surface area and better conductivity, whilst the MIP layer provided the selectivity of the sensor to doxycycline when compared to analysis of other antibiotics. This sensor was applied to human serum samples for DC detection.

A biosensor was developed using polymerised microporous metal-organic framework directly onto the gold electrode surface, and p-aminothiophenol was electropolymerized [98]. Extremely low detection limits of $0.22 \mathrm{fM}$ were achieved in honey in the recovery range of $101.8 \%-106.0 \%$. Gold nanoparticles were used as a signal amplifier due to their small size, great stability, great conductivity and good catalytic activity.

\subsubsection{Aptasensors}

Aptamers are fragments of DNA that fold in a predictable manner to create a ligand with a high affinity for a biological target molecule [133]. They can be also classified as 'chemical antibodies' and are attractive candidates for biosensors because they can be synthetically produced once a candidate has been identified. Aptamer candidate sequences are identified through the systematic evolution of ligands by the exponential enrichment (SELEX) process [134]. The SELEX process enables the fabrication of aptamers also for 
non-immunogenic and toxic targets, such as antimicrobial residues. They are also stable and are not affected by temperature; however, for optimal performance, the $\mathrm{pH}$ and ionic strength of the electrolyte solution must be constant $[135,136]$. A comprehensive review by Li et al. focuses on electrochemical biosensors using aptamers for analysis of food and water samples [137]. Figure 9 is a generic schematic diagram of the detection method of an aptasensor.

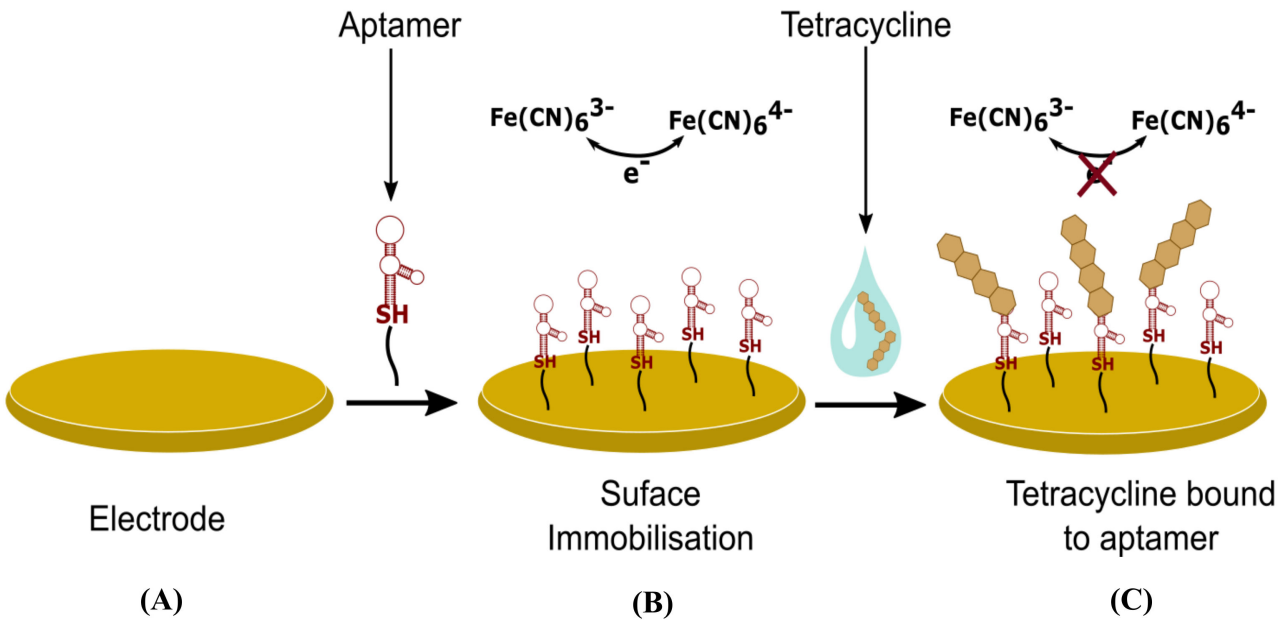

Figure 9. A schematic example of aptamer sensor for detection of TC. (A) The gold electrode surface is cleaned to remove contaminants. (B) Aptamer containing a thiol (SH) linker is immobilised to the electrode surface. At this stage, an alkanethiol passivation layer is also often added to the surface. A redox couple such as $\mathrm{FeCN}(6)^{3-} /{ }^{4-}$ can then be used to test for changes in the electrode surface. (C) When TC binds to the surface, a change in the Faradaic current is observed through impedance spectroscopy or voltammetric detection techniques. Adapted from Mehennaoui et al. [138].

A classic example of an electrochemical sensor for tetracycline detection developed using aptamers as the bioreceptor was reported by Kim et al. [107]. The biotin labelled aptamer sequence was immobilized on a gold WE, and it was selected to specifically bind to tetracycline. The CE was also made of gold with a silver RE. The aptasensor showed good selectivity to TC. This was demonstrated when a mixture of TC:OTC:DC was also introduced to the sensor, and it picked up only the TC, which had proved the high specificity of the selected aptamer. The limit of detection of this aptasensor was $10 \mathrm{nM}$ which is much lower than the MRL for TC, mentioned in the previous section.

An innovative approach was reported by Rad et al. combining tetracycline-sequenced aptamers and molecularly imprinted polymers, immobilised one after another on the electrode surface [99]. The working electrode material of choice was glassy carbon with gold nanoparticles. Dopamine was used as an additional 'seal' on top of the aptamer. Then, tetracycline was extracted from the aptamer sequence on the electrode surface, leaving empty cavities that are to be filled by potentially present TC in the introduced sample. The new TC molecules falling into the cavities essentially produce a charge on the redox probe, which is measured at a peak voltage of $0.22 \mathrm{~V}$ and thus achieving a limit of detection as low as $144 \mathrm{fM}$.

The detection of OTC with a two-electrode system using aptamer-based single-walled carbon nanotubes has also been carried out by Yildirim-Tirgil et al. [110]. The investigators had achieved not only very low detection limits and an extremely fast response time of only 10 min but also good reproducibility, suggesting that this approach could form the basis of a commercial solution.

Multi-walled carbon nanotubes (MWCNTs) have been widely used as the basis for a number of biosensors for the detection of tetracycline. MWCNTs on the surface of an electrode had been used as an amplifier in a study by Zhou et al., providing a larger and denser 
surface for the aptamers to attach [111]. Acid treatment was applied to MWCNTs before coating on the glassy carbon electrode by providing an excellent electrical conductivity and enhancing the charge transport. This amplification had resulted in higher sensitivity and great selectivity of the biosensor when it was compared to the results from a performance without the MWCNT coating.

\subsection{Limitations of Existing Sensors and Future Needs}

As discussed, biosensors offer promising alternatives to current antimicrobial residue testing methods for milk. However, there are limitations to existing platforms that should be a priority for future researchers in this area to facilitate full-time manufacturing and use.

\subsubsection{Specificity and Sensitivity}

Firstly, sensor specificity is essential to avoid unacceptable levels of false-positive results [139]. In this review, different types of bioreceptors were discussed as well as direct detection of tetracyclines on a modified electrode surface. False-positive results can be a factor derived not only from a direct detection method but also from the similarity of the chemical structures of several antibiotics from the same class, such as tetracyclines. Hence, the use of a highly specific biological material must be carefully considered prior to immobilisation.

Another parameter used for evaluation is the sensitivity of a platform. The set MRL values for all antibiotics are guidance for target limits of detection; however, many of the biosensor strategies discussed in this paper do not meet the current threshold levels. This may not be a barrier to sensors that are used to detect residues in a milk sample from a single cow but means that sensitivity must improve for applications where testing of milk prior to consumption is required.

In recent years, working electrode surface modification with nanomaterials had become a widely-used technique for signal amplification. The use of nanomaterials in the reported examples of electrochemical biosensors in Table 4 was highlighted where applicable. Materials such as gold nanoparticles, graphene oxide and carbon nanotubes are attractive options due to their advantageous mechanical and electrical properties. These are discussed in more depth in a review by Alsaiari et al. [140].

\subsubsection{Sensor Cost}

Biosensor cost is also an important factor both in terms of the design development cost and also the recurring consumable cost. Electrochemical devices are advantageous because production costs can be very low, but this is also dependent upon scales of economy and market size. Therefore, biosensor strategies that are adaptable to different applications are more attractive so that scales of the economy can be achieved.

\subsubsection{Sample Handling}

Electrochemical detection offers the ability to shrink the sensing platform to make it easier to operate as well as enabling multi-sites for analysis. Microfluidic platforms are an innovative approach to tackle this challenge and offer a point-of-care monitoring system not only for environmental but also for clinical and medical samples. A developed electrochemical platform by Kling et al. had introduced eight sites for analysis, and the required sample volume was reduced drastically [141]. Tetracycline and pristinamycin were detected simultaneously in human plasma, achieving very low limits of detection of 6.33 and $9.22 \mathrm{ng} / \mathrm{mL}$, respectively. A comprehensive review of microfluidic devices for milk analysis was reported by $\mathrm{Ng}$ et al. [142].

A future perspective is the fabrication of a multi-channel microfluidic platform that might be implemented in the milking machinery to monitor antibiotic residues directly before milk reaches the bulk tank. The challenges with its application in real-life conditions may, however, include biofouling on the electrode surface. This might interfere with the immobilised molecules and disrupt the biorecognition reaction, hence, result in false- 
positive or false-negative values. Antifouling strategies were discussed in a thorough review by Lin et al. [143].

\section{Conclusions}

When treated with antibiotic drugs, cows secrete a proportion of these as residues in milk, rendering it unfit for human consumption. Maximum residue limits are set globally to maintain the presence of antibiotics in food and avoid human health risks such as possible allergic reactions. To avoid health, environmental and financial risks imposed by this, the dairy industry is obliged to perform tests on raw milk within the supply chain. Here, we reviewed the methods currently employed by the dairy industry, which include screening and confirmatory tests and highlighted the limitations of existing commercially available testing approaches. Electrochemical biosensors are then outlined as an alternative for low-cost, rapid detection and could be suitable for real-time analysis. In particular, the electrochemical detection method is an attractive choice due to its high specificity and low-cost manufacturing. In recent years, the development of electrochemical biosensors has expanded and improved with the synthesis of aptamers; however, further research is still required to support the detection of the complete family of tetracyclines and also for the concurrent detection of multiple different residues.

Author Contributions: Conceptualization, M.R.R., F.L.H. and A.C.W.; writing-original draft preparation, M.R.R.; writing-review and editing, M.R.R., D.K.C. and M.H.; funding acquisition, A.C.W., F.L.H., D.K.C. and M.H. All authors have read and agreed to the published version of the manuscript.

Funding: This article is part of a Ph.D. program funded by the Engineering and Physical Sciences Research Council (EPSRC) and CENSIS Innovation centre, grant number EP/T517938/1. The APC was funded by the Andersonian Library.

Institutional Review Board Statement: Not applicable.

Informed Consent Statement: Not applicable.

Conflicts of Interest: The authors declare no conflict of interest. The funders had no role in the design of the study; in the writing of the manuscript, or in the decision to publish the results.

\section{References}

1. Aminov, R.I. A brief history of the antibiotic era: Lessons learned and challenges for the future. Front. Microbiol. 2010, 1. [CrossRef]

2. Prestinaci, F.; Pezzotti, P.; Pantosti, A. Antimicrobial resistance: A global multifaceted phenomenon. Pathog. Glob. Health 2015, 109, 309-318. [CrossRef] [PubMed]

3. Sachi, S.; Ferdous, J.; Sikder, M.H.; Hussani, S.A.K. Antibiotic residues in milk: Past, present, and future. J. Adv. Vet. Anim. Res. 2019, 6, 315-332. [CrossRef] [PubMed]

4. Edqvist, L.-E.; Pedersen, K.B. Antimicrobials as growth promoters: Resistance to common sense. In Late Lessons from Early Warnings: The Precautionary Principle 1896-2000; European Environment Agency: København, Denmark, 2000.

5. Uberoi, E. UK Dairy Industry Statistics. 2020. Available online: https://commonslibrary.parliament.uk/research-briefings/sn02721/ (accessed on 3 February 2021).

6. Quintanilla, P.; Cornacchini, M.; Hernando, M.I.; Molina, M.P.; Escriche, I. Impact of the presence of oxytetracycline residues in milk destined for the elaboration of dairy products: The specific case of mature goat cheese. Int. Dairy J. 2020, 101, 104595. [CrossRef]

7. Cogan, T.M. Susceptibility of Cheese and Yoghurt Starter Bacteria to Antibiotics. 1972. Available online: http://aem.asm.org/ (accessed on 10 February 2021).

8. Sarmah, A.K.; Meyer, M.T.; Boxall, A.B.A. A global perspective on the use, sales, exposure pathways, occurrence, fate and effects of veterinary antibiotics (VAs) in the environment. Chemosphere 2006, 65, 725-759. [CrossRef] [PubMed]

9. Pawar, N.; Chopde, S.; Deshmukh, M. Interaction between some probiotics and Listeria monocytogenes in fermented milk products. J. Food Process. Technol. 2012, 10. [CrossRef]

10. Albright, J.L.; Tuckey, S.L.; Woods, G.T. Antibiotics in Milk-A Review. J. Dairy Sci. 1961, 44, 779-807. [CrossRef]

11. Kivirand, K.; Kagan, M.; Rinken, T. Biosensors for the detection of antibiotic residues in milk. In Biosensors-Micro and Nanoscale Applications; InTech: Rijeka, Croatia, 2015. [CrossRef]

12. Commission Regulation (EU) No. 37/2010. 2010. Available online: https:/ / eur-lex.europa.eu/LexUriServ/LexUriServ.do?uri=OJ: L:2010:015:0001:0072:EN:PDF (accessed on 15 December 2020). 
13. Ziv, G.; Sulman, F.G. Absorption of Antibiotics by the Bovine Udder. J. Dairy Sci. 1975, 58, 1637-1644. [CrossRef]

14. Boisseau, J.; Moretain, J.P. Drug excretion by the mammary gland. In Veterinary Pharmacology and Toxicology; Springer: Amsterdam, The Netherlands, 1983; pp. 193-202. [CrossRef]

15. EMEA. Commitee for Veterinary Medicinal Products Note for Guidance for the Determination of Withdrawal Periods for Milk, 2000. Available online: https://www.ema.europa.eu/en/determination-withdrawal-periods-milk (accessed on 9 December 2020).

16. Chopra, I.; Roberts, M. Tetracycline Antibiotics: Mode of Action, Applications, Molecular Biology, and Epidemiology of Bacterial Resistance. Microbiol. Mol. Biol. Rev. 2001, 65, 232-260. [CrossRef] [PubMed]

17. Borriello, P.; Broadfoot, F.; Healey, K.; Neale, D.; Pickering, A.; Sabzikari, S. UK Veterinary Antibiotic Resistance and Sales Surveillance Report, 2020. Available online: www.gov.uk/government/organisations/veterinary-medicines-directorate (accessed on 29 April 2021).

18. Food Standards Agency. Information and Guidance on the Testing of Milk for Antibiotic Residues; Food Standards Agency: London, UK, 2015.

19. Bilal, M.; Mehmood, S.; Rasheed, T.; Iqbal, H.M.N. Antibiotics traces in the aquatic environment: Persistence and adverse environmental impact. Curr. Opin. Environ. Sci. Health 2020, 13, 68-74. [CrossRef]

20. Ventola, C.L. The antibiotic resistance crisis: Causes and threats. Pharm. Ther. 2015, 4, 277-283.

21. Antimicrobial Resistance. Available online: https://www.who.int/news-room/fact-sheets/detail/antimicrobial-resistance (accessed on 1 December 2020).

22. O'Neil, J. Report on Antimicrobial Resistance. 2016. Available online: https://amr-review.org (accessed on 4 February 2021).

23. Bhalla, N.; Jolly, P.; Formisano, N.; Estrela, P. Introduction to biosensors. Essays Biochem. 2016, 60, 1-8. [CrossRef] [PubMed]

24. Pateraki, M.; Fysarakis, K.; Sakkalis, V.; Spanoudakis, G.; Varlamis, I.; Maniadakis, M.; Lourakis, M.; Ioannidis, S.; Cummins, N.; Schuller, B.; et al. Biosensors and Internet of Things in smart healthcare applications: Challenges and opportunities. In Wearable and Implantable Medical Devices; Elsevier: Amsterdam, The Netherlands, 2020; pp. 25-53. [CrossRef]

25. Gaudin, V. Advances in biosensor development for the screening of antibiotic residues in food products of animal origin-A comprehensive review. Biosens. Bioelectron. 2017, 90, 363-377. [CrossRef] [PubMed]

26. Majdinasab, M.; Mishra, R.K.; Tang, X.; Marty, J.L. Detection of antibiotics in food: New achievements in the development of biosensors. Trends Anal. Chem. 2020, 127, 115883. [CrossRef]

27. Bottari, F.; Blust, R.; de Wael, K. Bio(inspired) strategies for the electro-sensing of $\beta$-lactam antibiotics. Curr. Opin. Electrochem. 2018, 10, 136-142. [CrossRef]

28. Gustavsson, E.; Sternesjö, Å. Biosensor analysis of $\beta$-lactams in milk: Comparison with microbiological, immunological, and receptor-based screening methods. J. AOAC Int. 2004, 87, 614-620. [CrossRef] [PubMed]

29. Chen, C.; Wang, J. Optical biosensors: An exhaustive and comprehensive review. Analyst 2020, 145, 1605-1628. [CrossRef]

30. Mourad, G.; Bettache, G.; Medjekal, S. Composition and Nutritional Value of Raw Milk. 2014. Available online: https://www. researchgate.net/publication/278785108_Composition_and_nutritional_value_of_raw_milk (accessed on 21 October 2020).

31. Factors Affecting the Composition of Milk from Dairy Cows. 1988. Available online: https://www.ncbi.nlm.nih.gov/books/ NBK218193/ (accessed on 25 November 2020).

32. Ozdemir, Z.; Tras, B.; Uney, K. Distribution of hydrophilic and lipophilic antibacterial drugs in skim milk, cream, and casein. J. Dairy Sci. 2018, 101, 10694-10702. [CrossRef]

33. Veiga, R.P.; Paiva, J.A. Pharmacokinetics-pharmacodynamics issues relevant for the clinical use of beta-lactam antibiotics in critically ill patients. Crit. Care 2018, 22, 1-34. [CrossRef]

34. Papich, M.G. Florfenicol. In Saunders Handbook of Veterinary Drugs; Elsevier: Amsterdam, The Netherlands, 2016; pp. 327-329. [CrossRef]

35. Ziv, G.; Rasmussen, F. Distribution of Labeled Antibiotics in Different Components of Milk Following Intramammary and Intramuscular Administrations®. J. Dairy Sci. 1975. [CrossRef]

36. Barza, M.; Brown, R.B.; Shanks, C.; Gamble, C.; Weinstein, L. Relation between lipophilicity and pharmacological behavior of minocycline, doxycycline, tetracycline, and oxytetracycline in dogs. Antimicrob. Agents Chemother. 1975, 8, 713-720. [CrossRef] [PubMed]

37. Agwuh, K.N.; MacGowan, A. Pharmacokinetics and pharmacodynamics of the tetracyclines including glycylcyclines. J. Antimicrob. Chemother. 2006, 5, 256-265. [CrossRef]

38. MacGibbon, A.K.H.; Taylor, M.W. Composition and Structure of Bovine Milk Lipids. In Advanced Dairy Chemistry; Springer: Boston, MA, USA, 2006; Volume 2.

39. Kilara, A.; Vaghela, M.N. Whey proteins. In Proteins in Food Processing, 2nd ed.; Elsevier Inc.: Amsterdam, The Netherlands, 2018; pp. 93-126. [CrossRef]

40. Murgiano, L.; Timperio, A.M.; Zolla, L.; Bongiorni, S.; Valentini, A.; Pariset, L. Comparison of Milk Fat Globule Membrane (MFGM) proteins of Chianina and Holstein cattle breed milk samples through proteomics methods. Nutrients 2009, 1, 302-315. [CrossRef]

41. Bär, C.; Mathis, D.; Neuhaus, P.; Dürr, D.; Bisig, W.; Egger, L.; Portmann, R. Protein profile of dairy products: Simultaneous quantification of twenty bovine milk proteins. Int. Dairy J. 2019, 9, 167-175. [CrossRef] 
42. PubChem. Beta-Lactose. Available online: https://pubchem.ncbi.nlm.nih.gov/compound/beta-Lactose (accessed on 9 December 2020).

43. PubChem. D-Glucose. Available online: https://pubchem.ncbi.nlm.nih.gov/compound/D-Glucose (accessed on 9 December 2020).

44. PubChem. Dilinoleoylpalmitoylglycerol. Available online: https://pubchem.ncbi.nlm.nih.gov/compound/129854299 (accessed on 9 December 2020).

45. PubChem. 1-Palmitoyl-2-linoleoylphosphatidylcholine. Available online: https://pubchem.ncbi.nlm.nih.gov/compound/1Palmitoyl-2-linoleoylphosphatidylcholine (accessed on 9 December 2020).

46. Holland, J.W. Post-Translational Modifications of Caseins. In Milk Proteins; Elsevier Inc.: Amsterdam, The Netherlands, 2008; pp. 107-132. [CrossRef]

47. Fenelon, M.A.; Hickey, R.M.; Buggy, A.; McCarthy, N.; Murphy, E.G. Whey proteins in infant formula. In Whey Proteins: From Milk to Medicine; Elsevier: Amsterdam, The Netherlands, 2018; pp. 439-494. [CrossRef]

48. Roberts, M.C. Tetracycline therapy: Update. Clin. Infect. Dis. 2003, 3, 462-467. [CrossRef] [PubMed]

49. Papich, M.G. Oxytetracycline. In Saunders Handbook of Veterinary Drugs; Elsevier: Amsterdam, The Netherlands, 2016; pp. 595-598. [CrossRef]

50. Siljanoski, A.; Ciglarič, R.; Pezdir, T.; Lainšček, P.R.; Dolenc, J.; Starič, J.; Šinigoj-Gačnik, K. Detection of tetracycline and other antimicrobial residues in milk from cows with clinical mastitis treated by combination therapy. J. Dairy Res. 2018, 8, 321-326. [CrossRef]

51. Chopra, I. Glycylcyclines-Third generation tetracycline analogues. Exp. Opin. Investig. Drugs 1994, 3, 191-193. [CrossRef]

52. European Medicines Agency. Use of Glycylcyclines in Animals in the European Union: Development of Resistance and Possible Impact on Human and Animal Health. 2013. Available online: www.ema.europa.eu (accessed on 9 November 2020).

53. Nelson, M.L.; Levy, S.B. The history of the tetracyclines. Ann. N. Y. Acad. Sci. 2011, 1241, 17-32. [CrossRef] [PubMed]

54. Lorenzetti, A.S.; Sierra, T.; Domini, C.E.; Lista, A.G.; Crevillen, A.G.; Escarpa, A. Electrochemically Reduced Graphene OxideBased Screen-Printed Electrodes for Total Tetracycline Determination by Adsorptive Transfer Stripping Differential Pulse Voltammetry. Sensors 2019, 20, 76. [CrossRef] [PubMed]

55. Schnappinger, D.; Hillen, W. Tetracyclines: Antibiotic action, uptake, and resistance mechanisms. Arch. Microbiol. 1996, 165. [CrossRef] [PubMed]

56. Vojtova, V.; Urbanek, K. Pharmacokinetics of tetracyclines and glycylcyclines. Klin. Mikrobiol. Infekc. Lek. 2009, 15, 17-21.

57. Cyclo Spray, Product information, Statement on the Active Substance(s) and Other Ingredient(s). Available online: http: //www.baltivet.com/files /8813/9325/0464/Brochure_Cyclo_Spray.pdf (accessed on 9 December 2020).

58. Pfizer Laboratories Ltd. Terramycin LA, Product Information. Available online: https://www.farmacy.co.uk/terramycin-la-20 0mgml-injection-100ml/p501 (accessed on 9 December 2020).

59. Commitee for Veterinary Medicinal Products Oxytetracycline, Tetracycline, Chlortetracycline Summary Report (3); The European Agency for the Evaluation of Medicinal Products: Amsterdam, The Netherlands, 1995.

60. FDA. CFR—Code of Federal Regulations Title 21; FDA: Silver Spring, MD, USA, 2018.

61. Kurjogi, M.; Mohammad, Y.H.I.; Alghamdi, S.; Abdelrahman, M.; Satapute, P.; Jogaiah, S. Detection and determination of stability of the antibiotic residues in cow's milk. PLoS ONE 2019, 14. [CrossRef] [PubMed]

62. Kellnerová, E.; Navrátilová, P.; Borkovcová, I. Effect of pasteurization on the residues of tetracyclines in milk. Acta Vet. Brno 2014, 83, S21-S26. [CrossRef]

63. Gajda, A.; Nowacka-Kozak, E.; Gbylik-Sikorska, M.; Posyniak, A. Tetracycline antibiotics transfer from contaminated milk to dairy products and the effect of the skimming step and pasteurisation process on residue concentrations. Food Addit. Contam. Part A 2018, 35, 66-76. [CrossRef]

64. Aalipour, F.; Mirlohi, M.; Jalali, M.; Azadbakht, L. Dietary exposure to tetracycline residues through milk consumption in Iran. J. Environ. Health Sci. Eng. 2015, 13. [CrossRef] [PubMed]

65. Navrátilová, P.; Borkovcová, I.; Dračková, M.; Janštová, B.; Vorlová, L. Occurrence of Tetracycline, Chlortetracyclin, and Oxytetracycline Residues in Raw Cow's Milk. Czech J. Food Sci. 2009, 27, 379-385. [CrossRef]

66. Nemati, M.; Abbasi, M.M.; Babaei, H.; Ansarin, M.; Nourdadgar, A. Simultaneous Determination of Tetracyclines Residues in Bovine Milk Samples by Solid Phase Extraction and HPLC-FL Method. Adv. Pharm. Bull. 2011, 1, 34-39. [CrossRef]

67. Bahmani, K.; Shahbazi, Y.; Nikousefat, Z. Monitoring and risk assessment of tetracycline residues in foods of animal origin. Food Sci. Biotechnol. 2020, 29, 441-448. [CrossRef]

68. Das, Y.K.; Yavuz, O.; Atmaca, E.; Aksoy, A. Tetracycline antibiotics in raw cow's milk produced in Samsun Province, Turkey. Fresenius Environ. Bull. 2019, 28, 5982-5988.

69. Aga, D.S.; O'connor, S.; Ensley, S.; Payero, J.Ä.O.; Snow, D.; Tarkalson, D. Determination of the Persistence of Tetracycline Antibiotics and Their Degradates in Manure-Amended Soil Using Enzyme-Linked Immunosorbent Assay and Liquid Chromatography-Mass Spectrometry. J. Agric. Food Chem. 2005. [CrossRef]

70. Hamscher, G.; Sczesny, S.; Höper, H.; Nau, H. Determination of persistent tetracycline residues in soil fertilized with liquid manure by high-performance liquid chromatography with electrospray ionization tandem mass spectrometry. Anal. Chem. 2002, 74, 1509-1518. [CrossRef]

71. Daghrir, R.; Drogui, P. Tetracycline antibiotics in the environment: A review. Environ. Chem. Lett. 2013, 11, 209-227. [CrossRef] 
72. Carlotti, B.; Cesaretti, A.; Elisei, F. Complexes of tetracyclines with divalent metal cations investigated by stationary and femtosecond-pulsed techniques. Phys. Chem. Chem. Phys. 2012, 14, 823-834. [CrossRef] [PubMed]

73. Hartman, A.B.; Essiet, I.I.; Isenbarger, D.W.; Lindler, L.E. Epidemiology of tetracycline resistance determinants in Shigella spp. and enteroinvasive Escherichia coli: Characterization and dissemination of tet(A)-1. J. Clin. Microbiol. 2003, 41, 1023-1032. [CrossRef]

74. Keen, P.L.; Montforts, M.M.M. Antimicrobial Resistance in the Environment; John Wiley \& Sons: Hoboken, NJ, USA, 2012.

75. Adesoji, A.T.; Ogunjobi, A.A.; Olatoye, I.O.; Douglas, D.R. Prevalence of tetracycline resistance genes among multi-drug resistant bacteria from selected water distribution systems in southwestern Nigeria. Ann. Clin. Microbiol. Antimicrob. 2015, 14, 35. [CrossRef] [PubMed]

76. Baghani, A.; Mesdaghinia, A.; Rafieiyan, M.; Dallal, M.M.S.; Douraghi, M. Tetracycline and ciprofloxacin multiresidues in beef and chicken meat samples using indirect competitive ELISA. J. Immunoass. Immunochem. 2019, 4, 328-342. [CrossRef] [PubMed]

77. Ramatla, T.; Ngoma, L.; Adetunji, M.; Mwanza, M. Evaluation of antibiotic residues in raw meat using different analytical methods. Antibiotics 2017, 6. [CrossRef]

78. ISO. Milk and Milk Products-Determination of Antimicrobial Residues-Tube Diffusion Test. Available online: https://iso.org/ standard/43819.html (accessed on 11 February 2021).

79. ISO. Milk and Milk Products—Guidelines for the Standardized Description of Immunoassays or Receptor Assays for the Detection of Antimicrobial Residues. Available online: https://www.iso.org/standard/33421.html (accessed on 11 February 2021).

80. Hennart, S.L.A.; Faragher, J.; Boison, J.; Agin, J.; Mitchell, M. Validation of the delvotest SP NT DA. J. AOAC Int. 2012, 95, 252-260. [CrossRef]

81. Carlsson, Å.; Björck, L. Charm test II for confirmation of inhibitory substances detected by different microbial assays in herd milk. J. Food Prot. 1991, 54. [CrossRef] [PubMed]

82. Euber, J.R.; Brunner, J.R. Determination of Lactose in Milk Products by High-Performance Liquid Chromatography. J. Dairy Sci. 1979, 62, 685-690. [CrossRef]

83. Lee, Y.H.; Mutharasan, R. Biosensors. In Sensor Technology Handbook; Elsevier Inc.: Amsterdam, The Netherlands, 2005; pp. 161-180. [CrossRef]

84. Ping, J.; Wang, Y.; Fan, K.; Tang, W.; Wu, J.; Ying, Y. High-performance flexible potentiometric sensing devices using free-standing graphene paper. J. Mater. Chem. B 2013, 1, 4781-4791. [CrossRef]

85. Grieshaber, D.; MacKenzie, R.; Vörös, J.; Reimhult, E. Electrochemical Biosensors—Sensor Principles and Architectures. Sensors 2008, 8, 1400-1458. [CrossRef] [PubMed]

86. Simões, F.R.; Xavier, M.G. Electrochemical Sensors. In Nanoscience and Its Applications; Elsevier Inc.: Amsterdam, The Netherlands, 2017; pp. 155-178. [CrossRef]

87. Yunus, S.; Jonas, A.M.; Lakard, B. Potentiometric Biosensors. In Encyclopedia of Biophysics; Springer: Berlin/Heidelberg, Germany, 2013. [CrossRef]

88. Sadeghi, S.J. Amperometric Biosensors. In Encyclopedia of Biophysics; Springer: Berlin/Heidelberg, Germany, 2013. [CrossRef]

89. Kim, M.; Iezzi, R.; Shim, B.S.; Martin, D.C. Impedimetric Biosensors for Detecting Vascular Endothelial Growth Factor (VEGF) Based on Poly(3,4-ethylene dioxythiophene) (PEDOT)/Gold Nanoparticle (Au NP) Composites. Front. Chem. 2019, 7. [CrossRef]

90. Besharati, M.; Tabrizi, M.A.; Molaabasi, F.; Saber, R.; Shamsipur, M.; Hamedi, J.; Hosseinkhani, S. Novel enzyme-based electrochemical and colorimetric biosensors for tetracycline monitoring in milk. Biotechnol. Appl. Biochem. 2020, bab.2078. [CrossRef]

91. Besharati, M.; Hamedi, J.; Hosseinkhani, S.; Saber, R. A novel electrochemical biosensor based on TetX2 monooxygenase immobilized on a nano-porous glassy carbon electrode for tetracycline residue detection. Bioelectrochemistry 2019, 128, 66-73. [CrossRef] [PubMed]

92. Pellegrini, G.E.; Carpico, G.; Coni, E. Electrochemical sensor for the detection and presumptive identification of quinolone and tetracycline residues in milk. Anal. Chim. Acta 2004, 520, 13-18. [CrossRef]

93. Conzuelo, F.; Campuzano, S.; Gamella, M.; Pinacho, D.G.; Reviejo, A.J.; Marco, M.P.; Pingarrón, J.M. Integrated disposable electrochemical immunosensors for the simultaneous determination of sulfonamide and tetracycline antibiotics residues in milk. Biosens. Bioelectron. 2013, 50, 100-105. [CrossRef] [PubMed]

94. Conzuelo, F.; Gamella, M.; Campuzano, S.; Reviejo, A.J.; Pingarrón, J.M. Disposable amperometric magneto-immunosensor for direct detection of tetracyclines antibiotics residues in milk. Anal. Chim. Acta 2012, 737, 29-36. [CrossRef] [PubMed]

95. Que, X.; Chen, X.; Fu, L.; Lai, W.; Zhuang, J.; Chen, G.; Tang, D. Platinum-catalyzed hydrogen evolution reaction for sensitive electrochemical immunoassay of tetracycline residues. J. Electroanal. Chem. 2013, 704, 111-117. [CrossRef]

96. Liu, X.; Zheng, S.; Hu, Y.; Li, Z.; Luo, F.; He, Z. Electrochemical Immunosensor Based on the Chitosan-Magnetic Nanoparticles for Detection of Tetracycline. Food Anal. Methods 2016, 9, 2972-2978. [CrossRef]

97. Zhao, H.; Wang, H.; Quan, X.; Tan, F. Amperometric Sensor for Tetracycline Determination Based on Molecularly Imprinted Technique. Proc. Environ. Sci. 2013, 18, 249-257. [CrossRef]

98. Bougrini, M.; Florea, A.; Cristea, C.; Sandulescu, R.; Vocanson, F.; Errachid, A.; Bouchikhi, B.; el Bari, N.; Jaffrezic-Renault, N. Development of a novel sensitive molecularly imprinted polymer sensor based on electropolymerization of a microporous-metalorganic framework for tetracycline detection in honey. Food Control 2016, 59, 424-429. [CrossRef] 
99. Rad, A.O.; Azadbakht, A. An aptamer embedded in a molecularly imprinted polymer for impedimetric determination of tetracycline. Microchim. Acta 2019, 186, 56. [CrossRef] [PubMed]

100. Xu, Z.; Jiang, X.; Liu, S.; Yang, M. Sensitive and selective molecularly imprinted electrochemical sensor based on multi-walled carbon nanotubes for doxycycline hyclate determination. Chin. Chem. Lett. 2019, 31, 185-188. [CrossRef]

101. Devkota, L.; Nguyen, L.T.; Vu, T.T.; Piro, B. Electrochemical determination of tetracycline using AuNP-coated molecularly imprinted overoxidized polypyrrole sensing interface. Electrochim. Acta 2018, 270, 535-542. [CrossRef]

102. Wang, H.; Zhao, H.; Quan, X.; Chen, S. Electrochemical Determination of Tetracycline Using Molecularly Imprinted Polymer Modified Carbon Nanotube-Gold Nanoparticles Electrode. Electroanalysis 2011, 23, 1863-1869. [CrossRef]

103. Mohammad-Razdari, A.; Ghasemi-Varnamkhasti, M.; Rostami, S.; Izadi, Z.; Ensafi, A.A.; Siadat, M. Development of an electrochemical biosensor for impedimetric detection of tetracycline in milk. J. Food Sci. Technol. 2020, 57, 4697-4706. [CrossRef]

104. Taghdisi, S.M.; Danesh, N.M.; Ramezani, M.; Abnous, K. A novel M-shape electrochemical aptasensor for ultrasensitive detection of tetracyclines. Biosens. Bioelectron. 2016, 85, 509-514. [CrossRef]

105. Zhang, J.; Zhang, B.; Wu, Y.; Jia, S.; Fan, T.; Zhang, Z.; Zhang, C. Fast determination of the tetracyclines in milk samples by the aptamer biosensor. Analyst 2010, 135, 2706-2710. [CrossRef]

106. Le, T.H.; Pham, V.P.; La, T.H.; Phan, T.B.; Le, Q.H. Electrochemical aptasensor for detecting tetracycline in milk. Adv. Nat. Sci. Nanosci. Nanotechnol. 2016, 7, 15008. [CrossRef]

107. Kim, Y.J.; Kim, Y.S.; Niazi, J.H.; Gu, M.B. Electrochemical aptasensor for tetracycline detection. Bioprocess Biosyst. Eng. 2010, 33, 31-37. [CrossRef]

108. Wu, Y.H.; Bi, H.; Ning, G.; Xu, Z.G.; Liu, G.Q.; Wang, Y.H.; Zhao, Y.L. Cyclodextrin subject-object recognition-based aptamer sensor for sensitive and selective detection of tetracycline. J. Solid State Electrochem. 2020, 24, 2365-2372. [CrossRef]

109. Yang, Y.; Yan, W.; Guo, Y.; Wang, X.; Zhang, F.; Yu, L.; Guo, C.; Fang, G. Sensitive and selective electrochemical aptasensor via diazonium-coupling reaction for label-free determination of oxytetracycline in milk samples. Sens. Actuat. Rep. 2020, 2, 100009. [CrossRef]

110. Yildirim-Tirgil, N.; Lee, J.; Cho, H.; Lee, H.; Somu, S.; Busnaina, A.; Gu, A.Z. A SWCNT based aptasensor system for antibiotic oxytetracycline detection in water samples. Anal. Methods 2019, 11, 2692-2699. [CrossRef]

111. Zhou, L.; Li, D.J.; Gai, L.; Wang, J.P.; Li, Y.B. Electrochemical aptasensor for the detection of tetracycline with multi-walled carbon nanotubes amplification. Sens. Actuat. B Chem. 2012, 162, 201-208. [CrossRef]

112. Shen, G.; Guo, Y.; Sun, X.; Wang, X. Electrochemical Aptasensor Based on Prussian Blue-Chitosan-Glutaraldehyde for the Sensitive Determination of Tetracycline. Nano Micro Lett. 2014, 6, 143-152. [CrossRef]

113. Benvidi, A.; Tezerjani, M.D.; Moshtaghiun, S.M.; Mazloum-Ardakani, M. An aptasensor for tetracycline using a glassy carbon modified with nanosheets of graphene oxide. Microchim. Acta 2016, 183, 1797-1804. [CrossRef]

114. Zhan, X.; Hu, G.; Wagberg, T.; Zhan, S.; Xu, H.; Zhou, P. Electrochemical aptasensor for tetracycline using a screen-printed carbon electrode modified with an alginate film containing reduced graphene oxide and magnetite (Fe3O4) nanoparticles. Microchim. Acta 2016, 183, 723-729. [CrossRef]

115. Tang, Y.; Liu, P.; Xu, J.; le Li, L.; Yang, L.; Liu, X.; Liu, S.; Zhou, Y. Electrochemical aptasensor based on a novel flower-like TiO2 nanocomposite for the detection of tetracycline. Sens. Actuat. B Chem. 2018, 258, 906-912. [CrossRef]

116. Pollap, A.; Kochana, J. Electrochemical Immunosensors for Antibiotic Detection. Biosensors 2019, 9. [CrossRef] [PubMed]

117. Van Regenmortel, M.H.V.; Azimzadeh, A. Determination of antibody affinity. J. Immunoassay 2000, 21, 211-234. [CrossRef]

118. Ferri, S.; Kojima, K.; Sode, K. Review of glucose oxidases and glucose dehydrogenases: A bird's eye view of glucose sensing enzymes. J. Diabetes Sci. Technol. 2011, 1068-1076. [CrossRef] [PubMed]

119. Walkiewicz, K.; Davlieva, M.; Wu, G.; Shamoo, Y. Crystal structure of bacteroides thetaiotaomicron TetX2: A tetracycline degrading monooxygenase at 2.8 Å resolution. Proteins 2011, 79, 2335-2340. [CrossRef] [PubMed]

120. Luan, Y.; Wang, N.; Li, C.; Guo, X.; Lu, A. Advances in the Application of Aptamer Biosensors to the Detection of Aminoglycoside Antibiotics. Antibiotics 2020, 9, 787. [CrossRef]

121. Lei, Y.; Chen, W.; Mulchandani, A. Microbial biosensors. Anal. Chim. Acta 2006, 568, 200-210. [CrossRef] [PubMed]

122. Munteanu, F.D.; Titoiu, A.M.; Marty, J.L.; Vasilescu, A. Detection of antibiotics and evaluation of antibacterial activity with screen-printed electrodes. Sensors 2018, 18. [CrossRef]

123. Allahverdiyeva, S.; Yardım, Y.; Şentürk, Z. Electrooxidation of tetracycline antibiotic demeclocycline at unmodified boron-doped diamond electrode and its enhancement determination in surfactant-containing media. Talanta 2021, 223, 121695. [CrossRef] [PubMed]

124. Alonso-Lomillo, M.; Dominguez-Renedo, O. Screen-Printed Biosensors in Drug Analysis. Curr. Pharm. Anal. 2017, 13, 169-174. [CrossRef]

125. Freire, R.S.; Pessoa, C.A.; Mello, L.D.; Kubota, L.T. Direct electron transfer: An approach for electrochemical biosensors with higher selectivity and sensitivity. J. Braz. Chem. Soc. 2003, 14, 230-243. [CrossRef]

126. Asadollahi-Baboli, M.; Mani-Varnosfaderani, A. Rapid and simultaneous determination of tetracycline and cefixime antibiotics by mean of gold nanoparticles-screen printed gold electrode and chemometrics tools. Measurement 2014, 47, 145-149. [CrossRef]

127. Anderson, C.R.; Rupp, H.S.; Wu, W.H. Complexities in tetracycline analysis-Chemistry, matrix extraction, cleanup, and liquid chromatography. J. Chromatogr. A 2005, 1075, 23-32. [CrossRef] 
128. Filik, H.; Avan, A.A.; Aydar, S.; Ozyurt, D.; Demirata, B. Determination of Tetracycline on the Surface of a High- Performance Graphene Modified Screen-Printed Carbon Electrode in Milk and Honey Samples. Curr. Nanosci. 2016, 12, 527-533. [CrossRef]

129. Song, B.; Zhou, Y.; Jin, H.; Jing, T.; Zhou, T.; Hao, Q.; Zhou, Y.; Mei, S.; Lee, Y.I. Selective and sensitive determination of erythromycin in honey and dairy products by molecularly imprinted polymers based electrochemical sensor. Microchem. J. 2014, 116, 183-190. [CrossRef]

130. Gui, R.; Guo, H.; Jin, H. Preparation and applications of electrochemical chemosensors based on carbon-nanomaterial-modified molecularly imprinted polymers. Nanoscale Adv. 2019, 1, 3325-3363. [CrossRef]

131. Piletsky, S.A.; Turner, A.P.F. Electrochemical Sensors Based on Molecularly Imprinted Polymers. Electroanalysis 2002, 14, 317-323. [CrossRef]

132. Clarindo, J.E.S.; Viana, R.B.; Cervini, P.; Silva, A.B.F.; Cavalheiro, E.T.G. Determination of Tetracycline Using a GraphitePolyurethane Composite Electrode Modified with a Molecularly Imprinted Polymer. Anal. Lett. 2020, 53, 1932-1955. [CrossRef]

133. Lan, L.; Yao, Y.; Ping, J.; Ying, Y. Recent advances in nanomaterial-based biosensors for antibiotics detection. Biosens. Bioelectron. 2017, 91, 504-514. [CrossRef]

134. Kaur, H. Recent developments in cell-SELEX technology for aptamer selection. Biochim. Biophys. Acta Gen. Subj. 2018, 1862, 2323-2329. [CrossRef] [PubMed]

135. Lakhin, A.V.; Tarantul, V.Z.; Gening, L.V. Aptamers: Problems, solutions and prospects. Acta Nat. 2013, 5, 34-43. [CrossRef]

136. Hianik, T.; Ostatná, V.; Sonlajtnerova, M.; Grman, I. Influence of ionic strength, $\mathrm{pH}$ and aptamer configuration for binding affinity to thrombin. Bioelectrochemistry 2007, 70, 127-133. [CrossRef]

137. Li, F.; Yu, Z.; Han, X.; Lai, R.Y. Electrochemical aptamer-based sensors for food and water analysis: A review. Anal. Chim. Acta 2019, 1051, 1-23. [CrossRef] [PubMed]

138. Mehennaoui, S.; Poorahong, S.; Jimenez, G.C.; Siaj, M. Selection of high affinity aptamer-ligand for dexamethasone and its electrochemical biosensor. Sci. Rep. 2019, 9, 6600. [CrossRef] [PubMed]

139. Sadana, A.; Sadana, N. Biosensor Performance Parameters and their Enhancement. In Fractal Analysis of the Binding and Dissociation Kinetics for Different Analytes on Biosensor Surfaces; Elsevier: Amsterdam, The Netherlands, 2008; pp. 19-53. [CrossRef]

140. Alsaiari, N.S.; Katubi, K.M.M.; Alzahrani, F.M.; Siddeeg, S.M.; Tahoon, M.A. The application of nanomaterials for the electrochemical detection of antibiotics: A review. Micromachines 2021, 12, 308. [CrossRef]

141. Kling, A.; Chatelle, C.; Armbrecht, L.; Qelibari, E.; Kieninger, J.; Dincer, C.; Weber, W.; Urban, G. Multianalyte Antibiotic Detection on an Electrochemical Microfluidic Platform. Anal. Chem. 2016, 88, 10036-10043. [CrossRef]

142. Ng, H.Y.; Lee, W.C.; Kung, C.t.; Li, L.C.; Lee, C.t.; Fu, L.M. Recent advances in microfluidic devices for contamination detection and quality inspection of milk. Micromachines 2021, 12. [CrossRef] [PubMed]

143. Lin, P.H.; Li, B.R. Antifouling strategies in advanced electrochemical sensors and biosensors. Analyst 2020, 145, 1110-1120. [CrossRef] 